DOE/LLW-114E-4

$$
\begin{gathered}
\text { FIFCENVED } \\
\text { :- } 11995 \\
\text { USTI }
\end{gathered}
$$

Greater-Than-Class C Low-Level Radioactive Waste Characterization

\title{
Appendix E-4: Packaging Factors for Greater-Than-Class C Low-Level Radioactive Waste
}

Greater-Than-Class C Low-Level Waste Management Program

September 1994

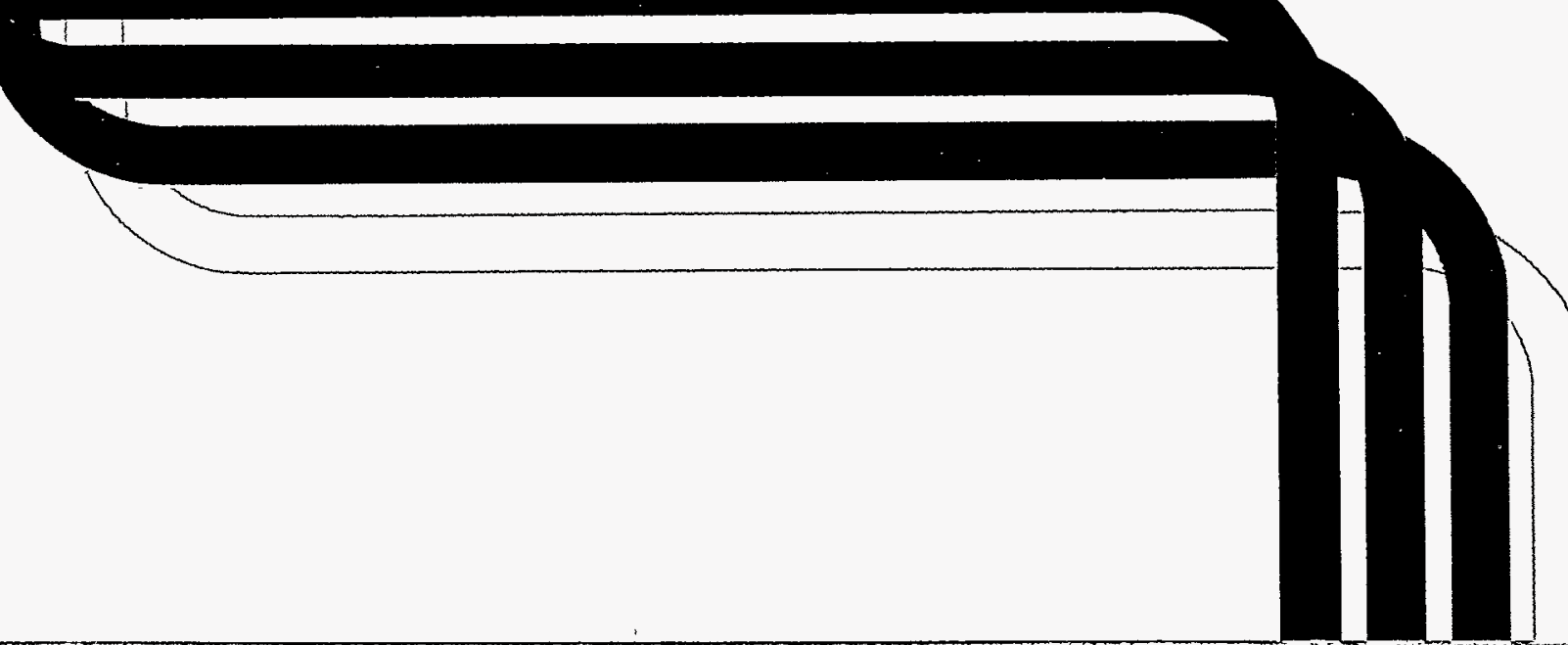




\title{
DISCLAIMER
}

This report was prepared as an account of work sponsored by an agency of the United States Government. Neither the United States Government nor any agency thereof, nor any of their employees, makes any warranty, express or implied, or assumes any legal liability or responsibility for the accuracy, completeness, or usefulness of any information, apparatus, product, or process disclosed, or represents that its use would not infringe privately owned rights. Reference herein to any specific commercial product, process, or service by trade name, trademark, manufacturer, or otherwise does not necessarily constitute or imply its endorsement, recommendation, or favoring by the United States Government or any agency thereof. The views and opinions of authors expressed herein do not necessarily state or reflect those of the United States Government or any agency thereof.

\section{Greater-Than-Class C Low-Level Radioactive Waste Characterization}

\section{Appendix E-4: Packaging Factors for Greater-Than-Class C Low-Level Radioactive Waste}

\author{
Geoff Quinn \\ Phil Grant \\ Mike Winberg \\ Karen Williams
}

Published September 1994

\section{Idaho National Engineering Laboratory Idaho Falls, Idaho 83415}




\section{DISCLAIMER}

Portions of this document may be illegible in electronic image products. Images are produced from the best available original document. 


\begin{abstract}
This report estimates packaging factors for several waste types that are potential greater-than-Class C (GTCC) low-level radioactive waste (LLW). The packaging factor is defined as the volume of a GTCC LLW disposal container divided by the as-generated or "unpackaged" volume of the waste loaded into the disposal container.

Packaging factors reflect any processes that reduce or increase an original unpackaged volume of GTCC LLW, the volume inside a waste container not occupied by the waste, and the volume of the waste container itself. Three values are developed that represent (a) the base case or most likely value for a packaging factor, (b) a high case packaging factor that corresponds to the largest anticipated disposal volume of waste, and (c) a low case packaging factor for the smallest volume expected.
\end{abstract}

GTCC LLW is placed in three categories for evaluation in this report: activated metals, sealed sources, and all other waste. 


\section{ACKNOWLEDGMENTS}

This report was initially prepared for EG\&G Idaho, Inc., by Geoff Quinn and Phil Grant of Wastren, Inc., and was issued in 1991 as DOE/LLW-114H, Packaging Factors for Greater-Than-Class C Low-Level Radioactive Wastes. It has since been updated by Mike Winberg and Karen Williams of EG\&G Idaho. Packaging experience gained since 1991 was considered in updating the calculations and changing the packaging factors reported in this study. Section 3 was rewritten and other changes were made as needed to support and be consistent with Revision 1 of Greater-Than-Class C Low-Level Radioactive Waste Characterization: Estimated Volumes, Radionuclide Activities, and Other Characteristics, (DOE/LLW-114, September 1994). 


\section{CONTENTS}

ABSTRACT $\ldots \ldots \ldots \ldots \ldots \ldots \ldots \ldots \ldots \ldots \ldots \ldots \ldots \ldots \ldots \ldots \ldots \ldots$ iii

ACRONYMS AND ABBREVIATIONS $\ldots \ldots \ldots \ldots \ldots \ldots \ldots \ldots \ldots \ldots \ldots \ldots$

1. INTRODUCTION $\ldots \ldots \ldots \ldots \ldots \ldots \ldots \ldots \ldots \ldots \ldots \ldots \ldots \ldots \ldots \ldots \ldots$

2. PACKAGING FACTORS FOR ACTIVATED METALS $\ldots \ldots \ldots \ldots \ldots \ldots \ldots \ldots$

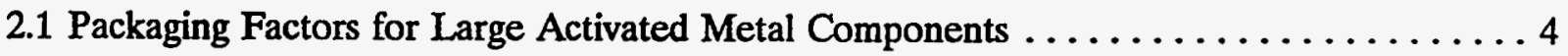

2.1.1 Background Information and Assumptions $\ldots \ldots \ldots \ldots \ldots \ldots \ldots \ldots \ldots \ldots$

2.1.2 Packaging Factor Estimates for LAMC $\ldots \ldots \ldots \ldots \ldots \ldots \ldots \ldots$

2.2 Packaging Factors for Small Activated Metal Components . . . . . . . . . 10

2.2.1 Background Information and Assumptions . . . . . . . . . . . . 10

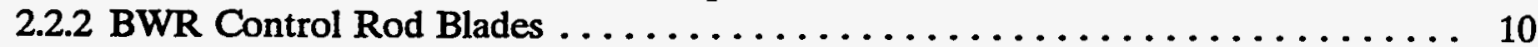

2.2.3 BWR and PWR In-Core Instruments $\ldots \ldots \ldots \ldots \ldots \ldots \ldots \ldots \ldots \ldots$

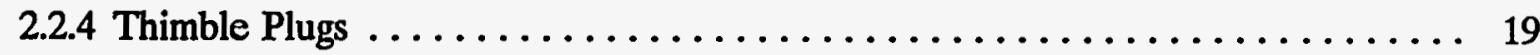

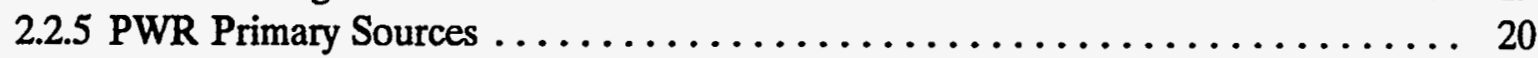

3. PACKAGING FACTORS FOR SEALED SOURCES $\ldots \ldots \ldots \ldots \ldots \ldots \ldots \ldots \ldots$

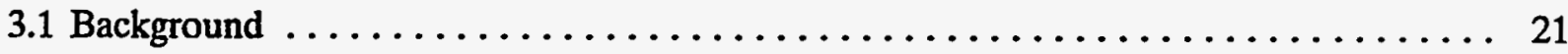

3.2 Types, Quantities, and Unpackaged Volumes of

Potential GTCC LLW Sealed Sources $\ldots \ldots \ldots \ldots \ldots \ldots \ldots \ldots \ldots \ldots \ldots \ldots$

3.3 Storage and Disposal Packaging Scenarios $\ldots \ldots \ldots \ldots \ldots \ldots \ldots \ldots \ldots \ldots$

3.4 Low, Base, and High Case PFs for Sealed Sources $\ldots \ldots \ldots \ldots \ldots \ldots \ldots \ldots$

3.4.1 Low Case Disposal PFs for Sealed Sources $\ldots \ldots \ldots \ldots \ldots \ldots \ldots \ldots \ldots \ldots$

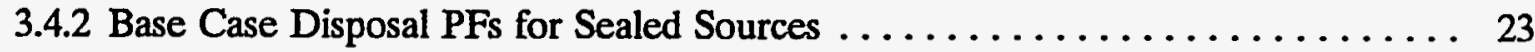

3.4.3 High Case Disposal PFs for Sealed Sources ................... 24

4. PACKAGING FACTORS FOR ALL OTHER GTCC LLW . . . . . . . . . . . 25

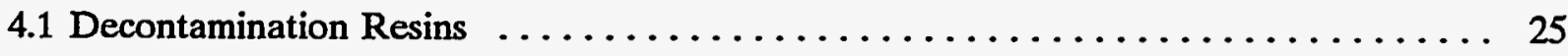

4.1.1 Packaging Factors for Spent Resins (Base, High, and Low Case) . . . . . . . 25

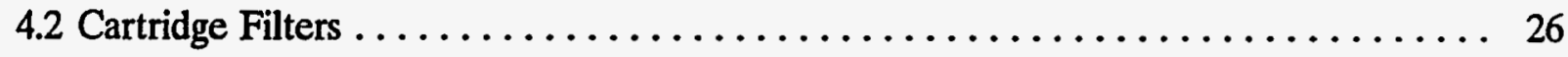


4.2.1 Packaging Factors for Cartridge Filters (Base, High, and Low Case) . . . . . . 26

4.3 Aqueous Liquids $\ldots \ldots \ldots \ldots \ldots \ldots \ldots \ldots \ldots \ldots \ldots \ldots \ldots \ldots \ldots \ldots \ldots$

4.3.1 Packaging Factors for Aqueous Liquids (Base, High, and Low Case) . . . . . . . 27

4.4 Solidified Liquids $\ldots \ldots \ldots \ldots \ldots \ldots \ldots \ldots \ldots \ldots \ldots \ldots \ldots \ldots \ldots \ldots$

4.4.1 Packaging Factors for Solidified Liquids (Base, High, and Low Case) $\ldots \ldots \ldots 28$

4.5 "Generic" Other GTCC LLW . . . . . . . . . . . . . . . . . . . 29

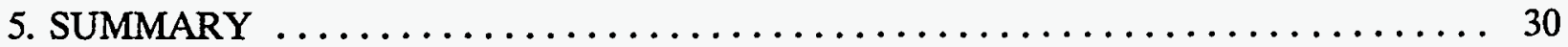

6. REFERENCES ............................. 47

FIGURES

1. Arrangement of LCB sections in a weight-constrained, cylindrical cross-section waste container 7

2. Arrangement of LCB sections in a weight-constrained, square cross-section waste container . 8

3. Arrangement of BWR control rod blades in a cylindrical cross-section waste container . . . 12

4. Arrangement of BWR control rod blades in a cylindrical cross-section waste container . . . 13

5. Arrangement of BWR control rod blades in a square cross-section waste container $\ldots \ldots .15$

6. Arrangement of BWR control rod blades in a square cross-section waste container . . . . 16

7. Arrangement of BWR control rod blades in a square cross-section waste container $\ldots \ldots 18$

\section{TABLES}

1. Potential GTCC LLW and generators $\ldots \ldots \ldots \ldots \ldots \ldots \ldots \ldots \ldots \ldots \ldots$

2. Packaging efficiencies for the TITAN truck cask without a spent fuel basket (weight-

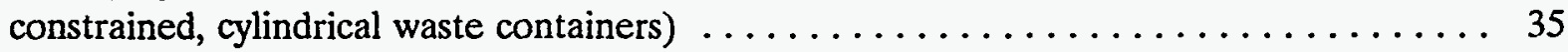

3. Dimensions of the Model IF-300 rail cask with basket removed $\ldots \ldots \ldots \ldots \ldots$

4. Packaging efficiencies for the Model IF-300 rail cask without a spent fuel basket (weightconstrained, cylindrical waste containers) $\ldots \ldots \ldots \ldots \ldots \ldots \ldots \ldots \ldots \ldots \ldots \ldots \ldots \ldots$ 
5. Packaging efficiencies for the Model 125-B rail cask without an inner containment vessel (weight-constrained, cylindrical waste containers) $\ldots \ldots \ldots \ldots \ldots \ldots \ldots \ldots \ldots$

6. Packaging efficiencies for casks with PWR spent fuel baskets (weight-constrained, square cross-section waste containers

7. Packaging efficiencies for all cases sorted in descending order of packaging efficiency for the entire LCB

8. Dimensions of the Model GA-4 truck cask

9. Dimensions of the Model BR-100 rail cask with the spent fuel basket replaced by a special square cavity basket

10. Summary of 1993 inventory of GTCC LLW sealed sources (held by specific licensees) after concentration averaging

11. Storage information for GTCC sealed sources (sources will be stored in their transport housing) $\ldots \ldots \ldots \ldots \ldots \ldots \ldots \ldots \ldots \ldots \ldots \ldots \ldots \ldots \ldots \ldots \ldots \ldots \ldots \ldots$

12. Storage and disposal $P F s$ for sealed sources $\ldots \ldots \ldots \ldots \ldots \ldots \ldots \ldots \ldots$

13. GTCC LLW packaging factors to be used in volume projections $\ldots \ldots \ldots \ldots \ldots$ 


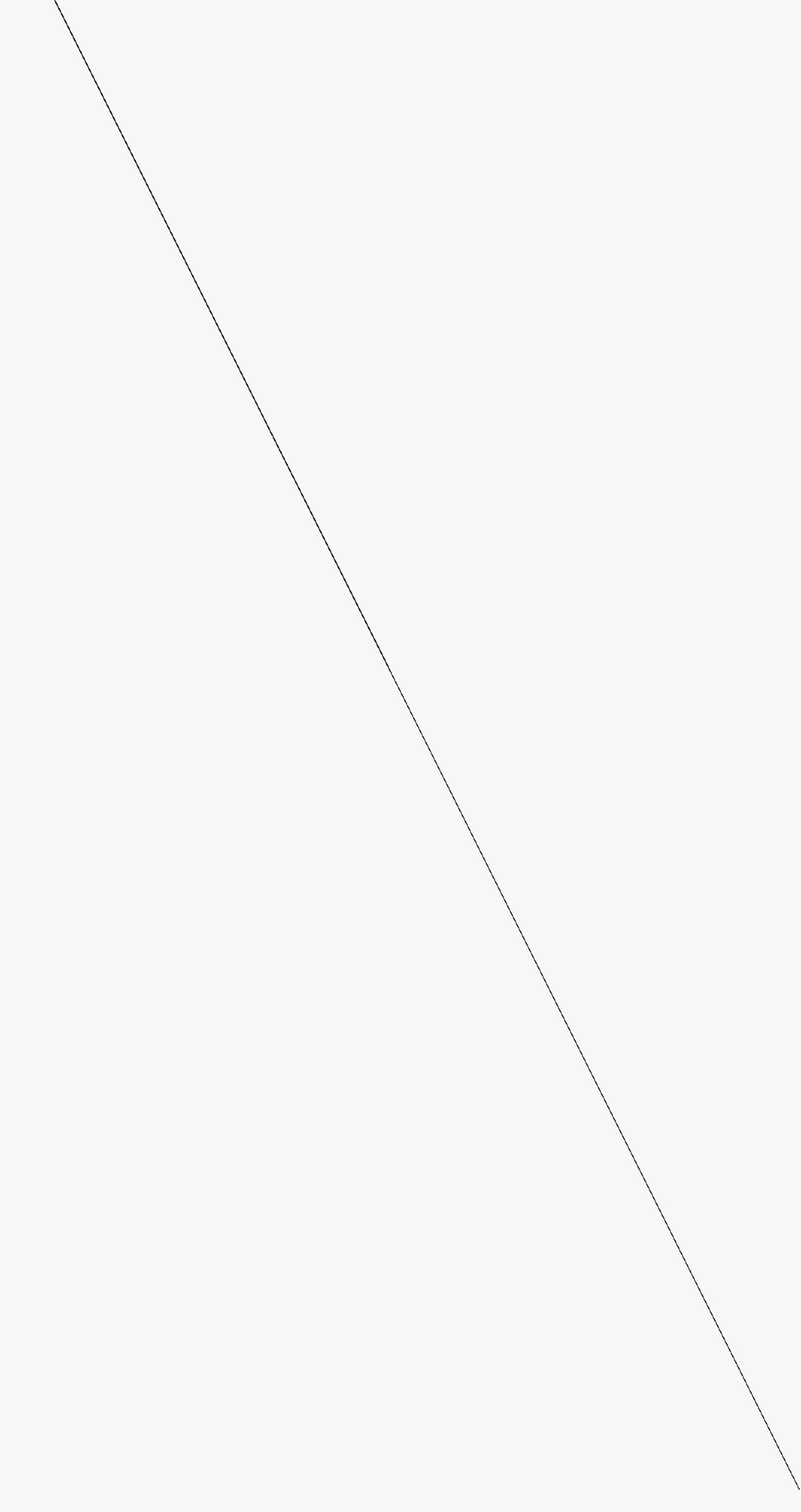




\section{ACRONYMS AND ABBREVIATIONS}

\begin{tabular}{ll} 
BWR & boiling water reactor \\
CRB & control rod blade \\
DOE & U.S. Department of Energy \\
GTCC & greater-than Class C \\
HIC & high-integrity container \\
ID & inside diameter \\
LAMC & large activated metal component \\
LCB & lower core barrel \\
LLW & low-level radioactive waste \\
OD & outside diameter \\
PE & packaging efficiency \\
PF & packaging factor \\
PWR & pressurized water reactor \\
SAMC & small activated metal component \\
THK & whickness \\
\hline
\end{tabular}




\section{Appendix E-4}

\section{Packaging Factors for Greater-Than-Class C Low-Level Radioactive Waste}

\section{INTRODUCTION}

This report develops and presents packaging factors (PFs) for several waste types that are expected to be greater-than-Class C (GTCC) low-level radioactive waste (LLW). The PF is defined as the volume of a GTCC LLW disposal container divided by the as-generated or "unpackaged" volume of the waste loaded into the disposal container. The PF will be used to estimate the packaged volume of GTCC LLW that the U.S. Department of Energy (DOE) will receive from commercial waste generators.

The volume of GTCC LLW generated by commercial facilities will not be the volume disposed of by DOE. The volume of the waste containers into which the GTCC LLW will be placed will constitute the disposal volume. Empty volume in a waste container will be minimized by the generators if minimization is made cost-effective. Although costs for DOE acceptance of GTCC LLW are not firm, a high cost per unit volume of waste container will tend to move generators toward minimizing void volume in a waste container for most GTCC LLW forms.

Since many GTCC LLW forms are similar to Class A, B, and C waste that can be disposed of in licensed disposal facilities, and since disposal costs at such facilities are high enough to require waste generators to pursue volume reduction operations, the current industry practices for volume reduction of Class $A, B$, and $C$ waste will likely be considered for treatment of GTCC LLW. If there is a relatively higher cost for disposal of GTCC LLW by DOE than for commercial disposal of LLW, additional technologies for volume reduction of GTCC LLW that are cost-effective would likely be introduced in the future. Likewise, some currently available, but uneconomical, technologies may become cost-effective in the future.

For the reader to understand the information presented in this report, the following terms are defined:

- Packaging efficiency (PE). The packaging efficiency is defined as the total unpackaged displaced volume of the waste that is placed in the disposal container, divided by the volume of the disposal container.

- Packaging factor (PF). The packaging factor is the reciprocal of the PE. It is then possible to take the PF for a type of waste and multiply it by the unpackaged volume to determine the volume increase or decrease that would be created by the packaging of that volume. PFs are calculated for all of the types of waste addressed in this report. 
The method for determining a PF considers the unpackaged volume of GTCC LLW before any treatment and packaging for disposal. A PF estimates what the volume will become when the waste is actually processed (if processed at all) and packaged into a waste disposal container for final disposal in the future. PFs include any processes that reduce or increase an original unpackaged volume of GTCC LLW, the volume inside a waste container not occupied by the GTCC LLW, and the volume of the waste container itself.

A set of three values is proposed as the range for a reasonable PF estimate for potential GTCC LLW types. These values are determined by considering existing LLW processing, handling, packaging, and transportation technologies, and the uncertainties in forecasting which technologies will be used later when GTCC LLW is treated, packaged, and transported for disposal. The three values represent (a) the base case or most likely value for a PF, (b) a high case PF that corresponds to the largest anticipated volume of waste for disposal, and (c) a low case PF for the smallest volume expected. The high and low cases are not proposed as worst-case values, but rather as reasonable values for the range of the base case.

The three categories of GTCC LLW evaluated in this report are: (a) activated metals, (b) sealed sources, and (c) all other waste. The specific types of materials evaluated in each category and the potential generators are listed in Table 1 (for better readability, all tables are located at the end of the report). 


\section{PACKAGING FACTORS FOR ACTIVATED METALS}

This section presents PFs for activated metal GTCC LLW. Section 2.1 presents PFs for the large components: core barrels, core shrouds, and support plates from boiling water reactors (BWRs) and pressurized water reactors (PWRs). Section 2.2 presents PFs for the small components: BWR control rod blades, in-core instruments, etc. For each type of component, background information and assumptions on the packaging scenarios are presented. The calculational models are then described and the results are provided. Estimates of the base, high, and low case PFs to be used in disposal volume projections are made after evaluating the results.

The waste containers for disposal of activated metal GTCC LLW are assumed to be transported from the generator site without later repackaging. Therefore, the waste container and its contents will be constrained to meet weight, volume, and shielding limits of the transport vessels, assumed here to be spent fuel shipping casks. This study assumes waste container dimensions near the sizes accommodated by either truck or rail spent fuel shipping casks. GTCC LLW waste acceptance criteria for disposal have not yet been established by DOE; however, weight, volume, decay heat, containment, and sub-criticality requirements will likely be easily met by payloads of activated metal GTCC LLW in spent fuel shipping casks.

An important consideration in the analyses is the assumption that different types of GTCC LLW are not mixed in the same waste disposal container. Waste packages are assumed to be homogenous; that is, only one type of activated metal is placed in a container. For example, only pieces of the core shroud are placed in one container, while pieces of the lower core barrel are placed in another. This assumption does not reflect the current practices for the packaging of LLW for burial at commercial LLW disposal sites. Within the guidelines acceptable at each disposal site, various small-size activated metal components are normally mixed together and disposed of as commercial LLW. While the acceptability of this practice in the future will influence the total volumes of potential GTCC LLW that ultimately are disposed of as GTCC LLW, this study purposely ignores the possibility that activated metal waste types will be mixed in determining the reasonable PFs for each specific waste type.

In using this approach (not mixing component types), a slightly higher PF results for each individual waste type than would be the case with mixing. Not mixing results in larger void spaces in containers, whereas the mixing of different types would enable small components to be placed into containers with pieces of large components, filling in some of the void spaces in those waste containers.

However, the PFs for unmixed waste types are expected to be only slightly higher than for the cases where mixing would be performed. As indicated by the range of PF values in the results, such a small difference should not affect the usefulness of the values proposed for the PFs. Also, this approach is helpful since it allows computer modeling of an individual waste type and avoids the problem of mathematically treating the many possibilities that arise if waste types were evaluated as mixed. 


\subsection{Packaging Factors for Large Activated Metal Components}

\subsubsection{Background Information and Assumptions}

The large activated metal components (LAMCs) considered in this study are the BWR and PWR core shrouds and support plates, and the PWR core barrels. These LAMCs are expected to be GTCC LLW when nuclear power plants are decommissioned. It is assumed that the activated metals are placed in a waste container, and the waste container is then placed inside the shipping cask.

In evaluating reasonable PFs for LAMCs, the unpackaged volume of the pieces that can be loaded into potential disposal containers is determined by the shapes and sizes of those pieces that can be cut to fit into the container being considered. Since the size of LAMCs at the reactor sites vary, and the size of waste containers acceptable to DOE is not fixed, many combinations of component and container sizes are possible for future packaging configurations for LAMCs. By looking at the range of possible combinations, a reasonable estimate of the most likely or base case $\mathrm{PF}$ is determined. Similarly, the high and low cases are based on the spread of values for the PFs for the many combinations.

In calculating the PFs, the size of the waste container is fixed, and several sections of the lower core barrel (LCB) are placed inside. The LCB is a cylindrical shell surrounding the reactor core. The size of the LCB is varied in these analyses to account for different reactor types. Other LAMCs are assumed to have similar packaging and PFs as the LCB.

Three types of constraints (activity, volume, and weight) were considered in determining packaging factors for LAMCs in waste containers.

2.1.1.1 Activity Constraints. This study does not constrain the total amount of curies in a disposal container of LAMCs, because there are too many variables and assumptions necessary to such a calculation. In reality, however, the generator must consider and work within any activity constraints when shipping the waste. The limit on curies in GTCC LLW disposal containers will be driven by U.S. Department of Transportation (DOT) regulations, which define the maximum external radiation field allowed by a shipping cask. The curie limit on the GTCC LLW container will therefore vary depending on the shipping cask used. Also, the generator can copackage any combination of waste within a container to limit the activity to comply with DOT requirements. Therefore, activity levels of a waste container will depend on the design of the shipping cask, the level of activation of the metal components, and the method of copackaging. Since these factors cannot be predicted, this study assumes that the generator will allow time for decay, select a cask, and copackage the GTCC LLW in such a way that activity constraints can be met and are not limiting.

2.1.1.2 Volume Constraints. This study has changed since 1991 to eliminate volume constraints from calculational models for shipment of LAMC GTCC LLW. Instead, it was recognized that weight limits of spent fuel shipping casks are reached before volume limits are. This is because a significant amount of the weight capacity of a transport vehicle (i.e., truck or 
railroad car) is required for shielding integral to a spent fuel shipping cask design, so the weight capacity remaining for allowable payloads is relatively small.

It is theoretically possible that in the future, low-radioactivity GTCC LLW could be transported in shipping casks with less shielding. Such casks would not impose the low weight limits required by the spent fuel shipping casks used for these calculational models, and volume constraints might indeed be limiting. However, in many cases, LAMC GTCC LLW from decommissioning can be as or more radioactive than spent fuel. In these cases, shielding would be required and the weight limits of spent fuel shipping casks would therefore apply. In reality, then, low-activity LAMC GTCC LLW would usually not be shipped separately in casks with less shielding, but would be mixed with the high-activity GTCC LLW to meet the activity limits discussed previously. In addition, using the same cask to make all shipments would be more efficient from a materials handling perspective. For these reasons, this study assumes use of spent fuel casks for transport of the GTCC LLW, with the attendant weight constraints rather than volume constraints.

2.1.1.3 Weight Constraints. In calculations for weight-constrained LAMC waste disposal containers, the number of LCB sections loaded into each container is limited so that the weight of the container is compatible with the payload weight limit of the shipping cask. It is apparent that the assumed weight constraints can severely limit the number of LCB sections that can be placed into each container. The calculational model for weight-constrained waste containers considers four types of shipping casks.

- $\quad$ TITAN truck cask. A newly designed spent fuel truck cask, the TITAN has a maximum allowable payload weight of $6,235 \mathrm{lb}$. It has interchangeable baskets for PWR or BWR spent fuel assemblies; with no baskets in place, there is a cylindrical cavity ( 23.75 in. diameter, 180 in. deep) into which a waste container of LAMC could be placed for transport. The waste container placed in the cask is assumed to have an outside diameter of 23.25 in., and a length of $164 \mathrm{in.}$

For the weight-constrained calculations, LCB sections were added to this cylindrical container until the TITAN truck cask's maximum payload weight was reached. Table 2 provides the results of the calculations, which show the effects on PEs as the inside diameter and thickness of the LCB are varied. The PEs for an entire LCB range from a low value of 0.206 to a high value of 0.222 . Figure 1 shows the reason for the low PEs for the case with an LCB with an inner diameter of 148 in. and thickness of 2.5 in. Nine to sixteen waste containers are needed to package an entire LCB.

- Model IF-300 rail cask. The Model IF-300 rail cask has a maximum allowable payload weight of $21,000 \mathrm{lb}$. With its basket removed, the cask has a cylindrical cavity diameter of 37.5 in. and a depth of 180.25 in. Table 3 provides dimensions of the Model IF-300 cask, the cylindrical waste container assumed to be placed inside the cask, and the waste envelope.

For the weight-constrained calculations, LCB sections were added to this cylindrical container until the IF-300 rail cask's maximum payload weight was reached. Table 4 provides the results of the calculations, which show the effects on PEs as the inside 
diameter and thickness of the LCB are varied. The PEs for an entire LCB range from a low value of 0.265 to a high value of 0.332 . Three to five waste containers are needed to package an entire LCB.

- Model 125-B rail cask. The Model 125-B rail cask has a maximum allowable payload weight of $57,565 \mathrm{lb}$. It has a cylindrical internal cavity with dimensions of $51.25 \mathrm{in}$. inside diameter $\times 190$ in. deep.

For the weight-constrained calculations, LCB sections were added to a cylindrical waste container in the 125-B rail cask until the maximum payload weight was reached. Table 5 provides the results of the calculations, which show the effects on PEs as the inside diameter and thickness of the LCB are varied. The PEs for an entire LCB range from a low value of 0.264 to a high value of 0.481 . One to two waste containers are needed to package an entire LCB.

- $\quad$ PWR spent fuel casks. Any shipping casks with baskets for PWR spent fuel assemblies have one or more square cross-section cavities into which waste containers of sectioned LCB could be placed for transport by either truck or rail. These calculations assume a maximum allowable payload weight of $1,515 \mathrm{lb}$ for each cask cavity position. Each square cross-section cavity is assumed to be $8.75 \mathrm{in}$. on a side, and deep enough to accept the waste container. To allow loading and unloading, a minimum clearance of $0.25 \mathrm{in}$. is assumed between each inside surface of the square cavity and the outside surface of a waste container.

To perform the calculations, the nominal outside dimension of a square cross-sectioned waste container was varied to limit the loaded weight to within shipping cask weight constraints. The container length was fixed at 164.5 in. These outer envelope dimensions are used in calculating the volume of the waste container. The space in the cask cavity not filled with the waste container is assumed to be filled by a lightweight spacer. Figure 2 illustrates packaging of LCB sections into a weight-constrained, square cross-sectioned waste container.

The results of the weight-constrained calculations are provided in Table 6 for casks with PWR fuel baskets. The results show the effect on PEs as the inside diameter and thickness of the LCB are varied for square cross-section waste containers. The PEs for an entire LCB range from a low value of 0.348 to a high value of 0.609 . Thirty-eight to 86 waste containers are needed to package an entire LCB. 


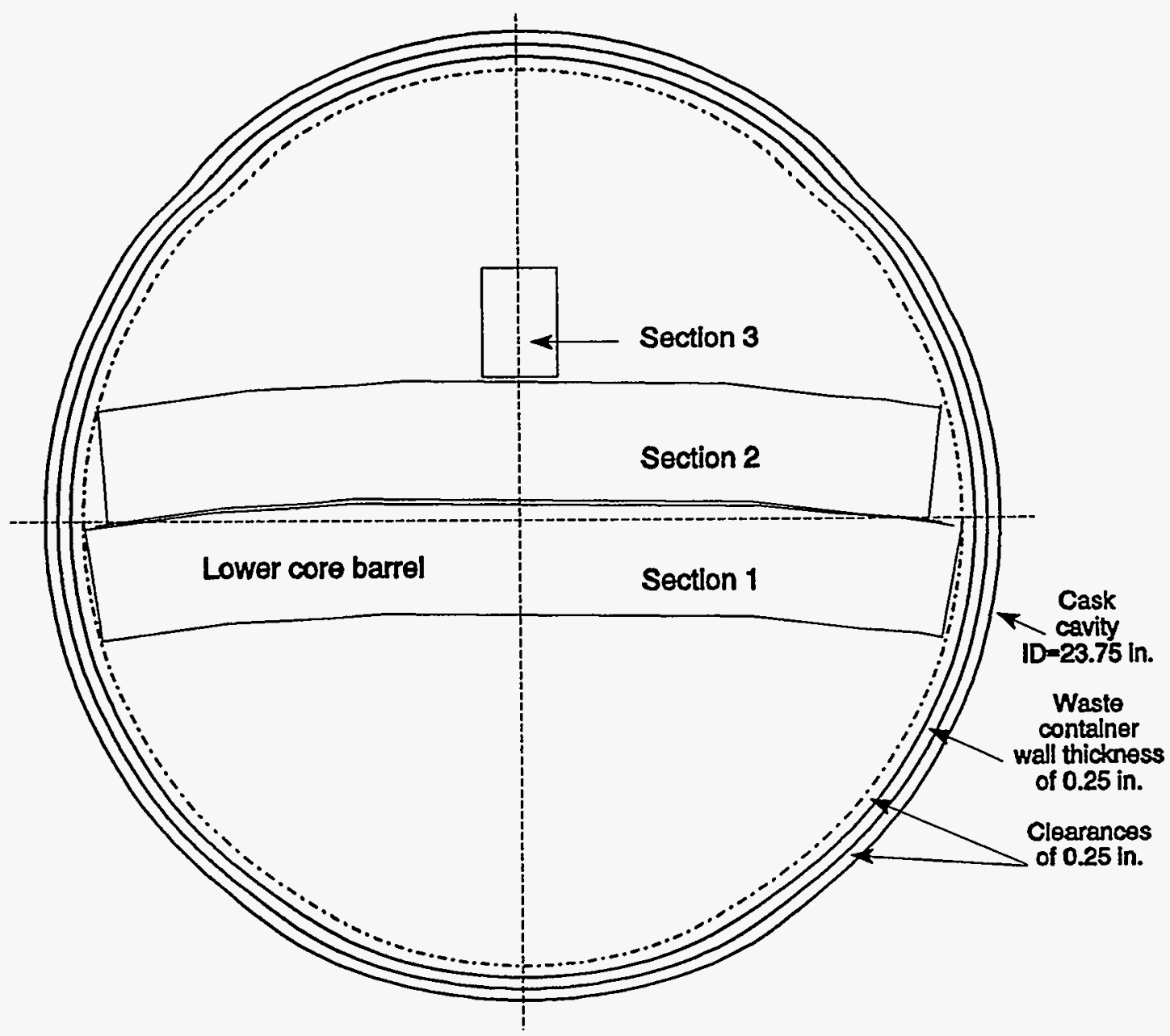

$00001 \pi$

Figure 1. Arrangement of LCB sections in a weight-constrained, cylindrical cross-section waste container.

Example: TITAN truck cask without basket

LCB dimensions: $\mathrm{ID}=148$ in. $\mathrm{THK}=2.5$ in. 


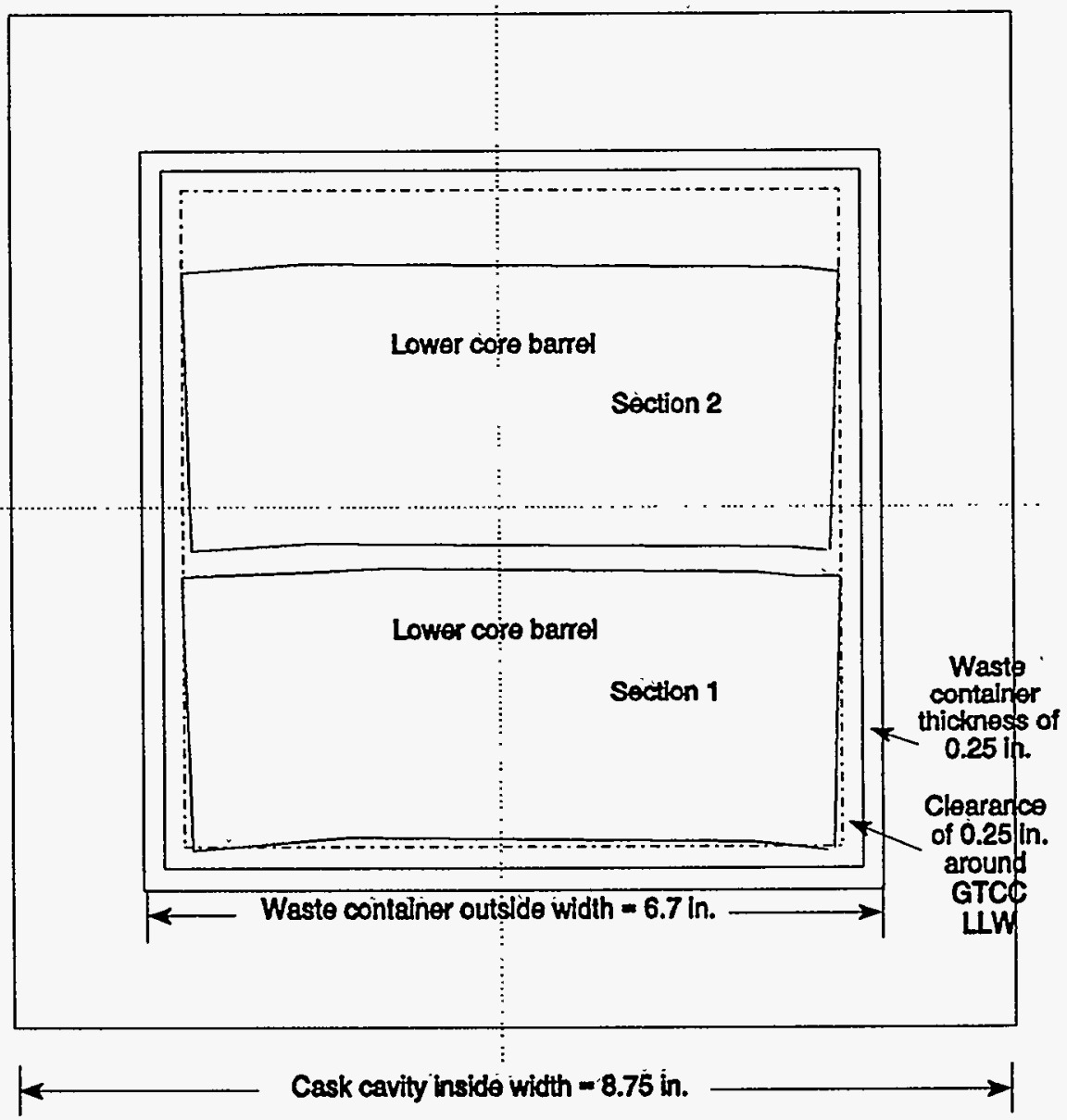

arosit

Figure 2. Arrangement of LCB sections in a weight-constrained, square cross-section waste container.

Example: PWR spent fuel cask with basket in place

LCB dimensions: $\mathrm{ID}=148$ in. $\mathrm{THK}=2.5 \mathrm{in}$. 


\subsubsection{Packaging Factor Estimates for LAMC}

Similar packaging and PFs were assumed for all LAMCs, although detailed calculations were only performed for LCBs. For LCBs, a total of 36 cases were evaluated, which represent nine different sizes of LCBs loaded into spent fuel casks in 4 weight-constrained waste containers. The resulting PE for each case represents a possible loading of LAMCs into a waste container. Based on the many PEs that were determined and that are summarized in Table 7, the proposed base case PF for LAMCs is 3 , or a PE of 0.33 . This value reflects the considerable number of uncertainties that will affect the actual PFs. These include the actual diameters and thicknesses of existing LCBs, the effect of flanges and protrusions that may be present on LCBs, the tolerances to which the sections of an $\mathrm{LCB}$ can be cut remotely underwater, the clearances that will be required between sections of an LCB for loading into a waste container, the types of casks to be used for transport, and the sizes of the waste containers that will be used. While some reactor sites may achieve a PF higher than 3 , others will likely not achieve even this high a value.

A PF of 3 (based on a PE of 0.33 ) is slightly higher than the average value of all of the results for the PF for an entire LCB. This value appears to be the most reasonable for a base case PF.

A PF of 5 (based on a PE of 0.2) is proposed for the high case for the range of PFs. This value represents the possible packaging variations yielding the largest packaged volume of LAMCs that would be expected for disposal. Several of the cases that had a PE of about 0.2 represent a combination of variables considered reasonable. Since these combinations of variables are possible, they may determine actual PEs. If these cases represent many of the LCBs in existence, a PF of 5 might be realized. Therefore, a PF of 5 is reasonable in the high case.

A PF of 2 (based on a PE of 0.5 ) is proposed for the low case. This value represents the smallest packaged volume of LAMCs that would be expected for disposal. Several of the cases had PEs of about 0.6 for an entire LCB. A value as high as the highest PE generated was not selected, since the theoretical aspects of this evaluation have not been tested against the realworld problems of cutting large components remotely to fit into tolerances as tight as those that were used in the calculations.

These PFs for the base, high, and low cases should be reasonable estimates, even if larger or smaller tolerances for remote cutting and handling actually occur. For example, changing the length of the sections placed in a container by 1 in. would not change the values for the proposed $\mathrm{PFs}$, since this reduction would have only a minor effect on the packaging efficiency calculations.

Note that this report has been changed since 1991 to eliminate consideration of the volumeconstrained models as well as some weight-constrained models for packaging of LAMC in spent fuel shipping casks. This is because it has been recognized since 1991 that LAMC packing configurations in those models were too optimistic in their assumed capability to tightly pack the waste. Experience has shown that it is very difficult to efficiently pack the waste, due to conditions such as remote handling, poor visibility, and cutting of the LAMC into variable shapes and sizes with rough edges. This study therefore does not consider the volume-constrained packing models and some weight-constrained models that were included in the 1991 study. 
As discussed previously, the assumption that mixing will not be permitted would tend to overestimate the packaged volume of LAMCs if such mixing is allowed, since small parts of other components could be used to fill the void spaces of a volume-constrained waste container.

Perhaps more significant, pieces of other components could be used to complete the filling of the last waste container only partially filled with pieces of a large component. As the data show, the PEs for a single, fully loaded waste container filled with sections of the LCB are higher than the overall PE for an entire LCB when the last filled waste container is only partially filled. The low $\mathrm{PE}$ of the last, partially filled waste container reduces the average for the group. The smaller the number of waste containers in the group, the larger this effect. Just using the space in the last, partially filled container would raise the overall $\mathrm{PE}$, thereby reducing the overall $\mathrm{PF}$.

\subsection{Packaging Factors for Small Activated Metal Components}

\subsubsection{Background Information and Assumptions}

The small activated metal components (SAMCs) considered in this study are BWR control rod blades and in-core instruments, as well as PWR thimble plugs, in-core instruments, and primary sources. These SAMCs are potential GTCC LLW during nuclear power plant operations and at decommissioning. Previous estimates of the PFs for SAMCs for current operations are not published and are based on the practice of mixing pieces of SAMCs in waste disposal containers sent to commercial LLW disposal sites.

In contrast to the LAMCs, which are characterized by a single large item with well-defined geometry and volume requiring disposal, the SAMCs consist of many small items generated during ongoing operations without a definite generation rate. The volume requiring disposal is therefore not as determinate as for the LAMCs. Also, since each item of the SAMCs is small compared to the internal volume of the waste containers previously considered for the LAMCs, there is a possibility that an insufficient amount of a specific SAMC waste type will be available to fill the volume in a single waste container.

The PFs for each of the SAMCs are based on calculational models or engineering judgements as described below. Each specific SAMC waste type is discussed individually. The models are based on filling a single waste container with a specific waste type. This assumes that a sufficient volume of the waste type will be available to fill the container.

\subsubsection{BWR Control Rod Blades}

A BWR control rod blade (CRB) consists of long, thin metal plates in the shape of an X. The plates sandwich a neutron poison material that controls the operation of the BWR plant. A CRB is almost $10 \mathrm{in}$. across, and the width of the metal plate sandwich is about 0.3 in. A CRB is approximately 175 in. long, and the end that is not inserted into the reactor core has a cylindrically shaped velocity limiter integral to the CRB assembly. A CRB is activated by neutrons when it is inserted into the core. Since not all of a CRB is inserted into the core, there is a radioactive "hot end" and a "cold end." These terms will be used to indicate which end of the CRB is more highly activated. 
Base Case. The evaluation of the base case PF assumes that the velocity limiter on the cold end is cut off and disposed of as commercial LLW. The current practice is to flatten the hot end between rollers and then place it into a cylindrical waste container. The volume of the hot end of the CRB is approximately $0.6 \mathrm{ft}^{3}$. The envelope dimensions of the flattened CRB are assumed to be $2 \times 10 \times 160$ in. Two sizes of cylindrical waste containers are evaluated for the base case; one is for transport in a Titan truck cask, and the other is for the IF-300 rail cask.

- TITAN spent fuel truck cask. This evaluation assumes the same cylindrical waste container as described in section 2.1.1.3 for the TITAN truck cask with the spent fuel basket removed.

Figure 3 shows an arrangement of flattened CRBs in the waste container. The 13 CRBs in the container have a displaced volume (not envelope dimension volume) of $7.8 \mathrm{ft}^{3}$. With a waste container outer volume of $40.29 \mathrm{ft}^{3}$, the PE for this size of container is 0.19 .

- Model IF-300 rail cask This evaluation assumes the same cylindrical waste container as described in section 2.1.1.3 for the IF-300 rail cask with its basket removed (see Table 3).

Figure 4 shows an arrangement of boxes that represent the flattened CRBs in the waste container. The $37 \mathrm{CRBs}$ in the container have a displaced volume (not envelope dimension volume) of $22.2 \mathrm{ft}^{3}$. With a waste container outer volume of $100.67 \mathrm{ft}^{3}$, the $\mathrm{PE}$ for this size of container is $\mathbf{0 . 2 2}$.

From these two results, the base case PE for BWR CRBs is 0.2 , or a PF of 5.

Low Case. The evaluation of the low-case PF assumes that the velocity limiter on the cold end is cut off and disposed of as commercial LLW. The hot end is flattened between rollers and then placed into a square cross-section waste container. The volume of the hot end of the CRB is approximately $0.6 \mathrm{ft}^{3}$. The envelope dimensions of the flattened CRB are assumed to be $2 \times$ $10 \times 160$ in.

Two sizes of square cross-section waste containers are evaluated for the low case. One is for transport in the Model GA-4 truck cask, and the other is for transport in the Model BR-100 rail cask.

- Model GA-4 truck cask. The new design Model GA-4 truck cask has a maximum allowable payload weight of $8,760 \mathrm{lb}$. It has a square cross-section cavity with $18 \mathrm{in}$. on a side, and a length of $167.25 \mathrm{in}$. This cask is evaluated for the case in which the spent fuel basket is removed from the cask cavity, allowing a GTCC LLW waste container to be transported. The outside width of the waste envelope is assumed fixed at $16.5 \mathrm{in}$. The length of the container was fixed at 164.5 in. The cask and container dimensions are presented in Table 8. 


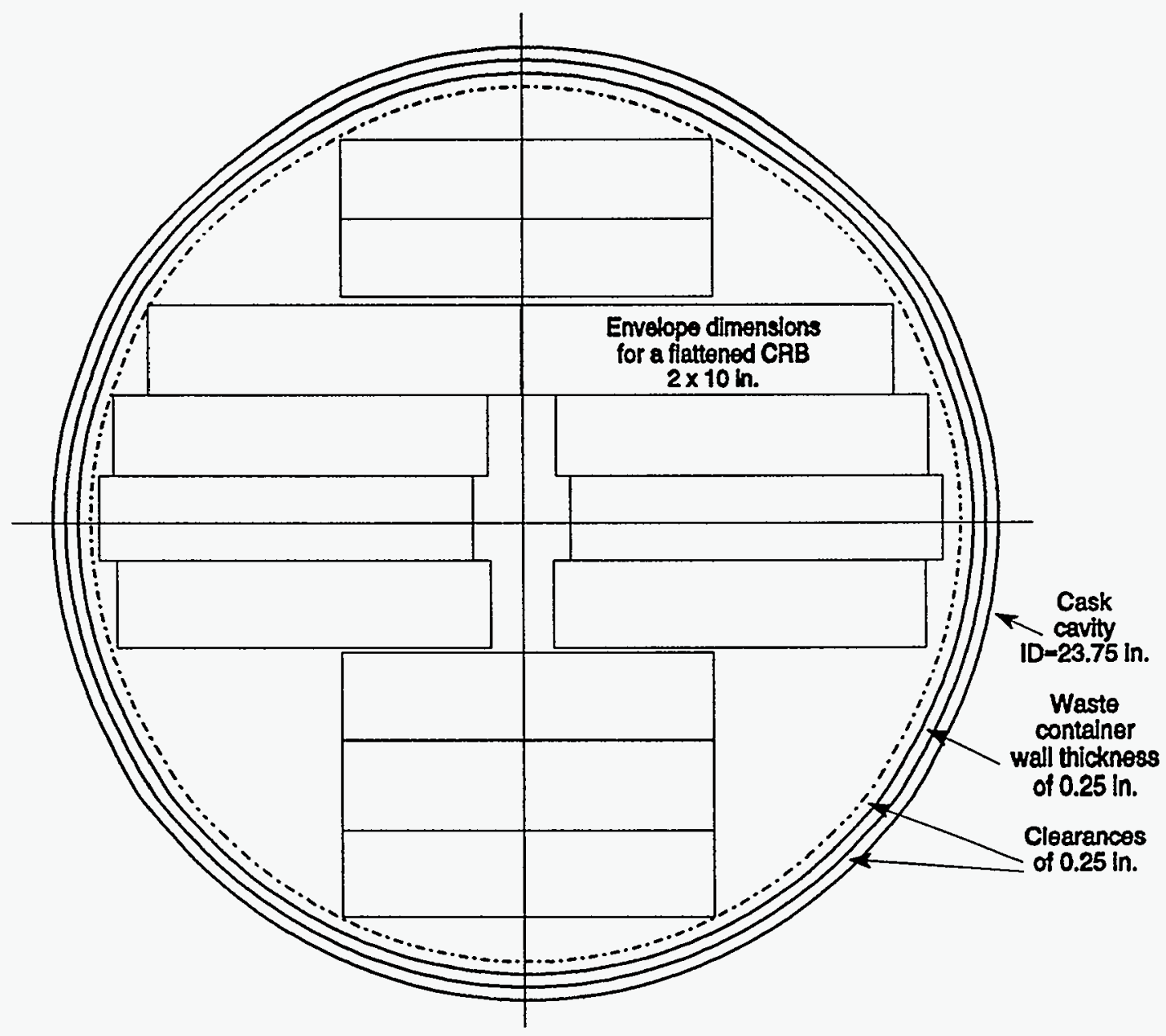

Das00170

Figure 3. Arrangement of BWR control rod blades in a cylindrical cross-section waste container.

Example: TITAN truck cask without basket

Flattened CRB envelope dimensions: $2 \times 10$ in. 


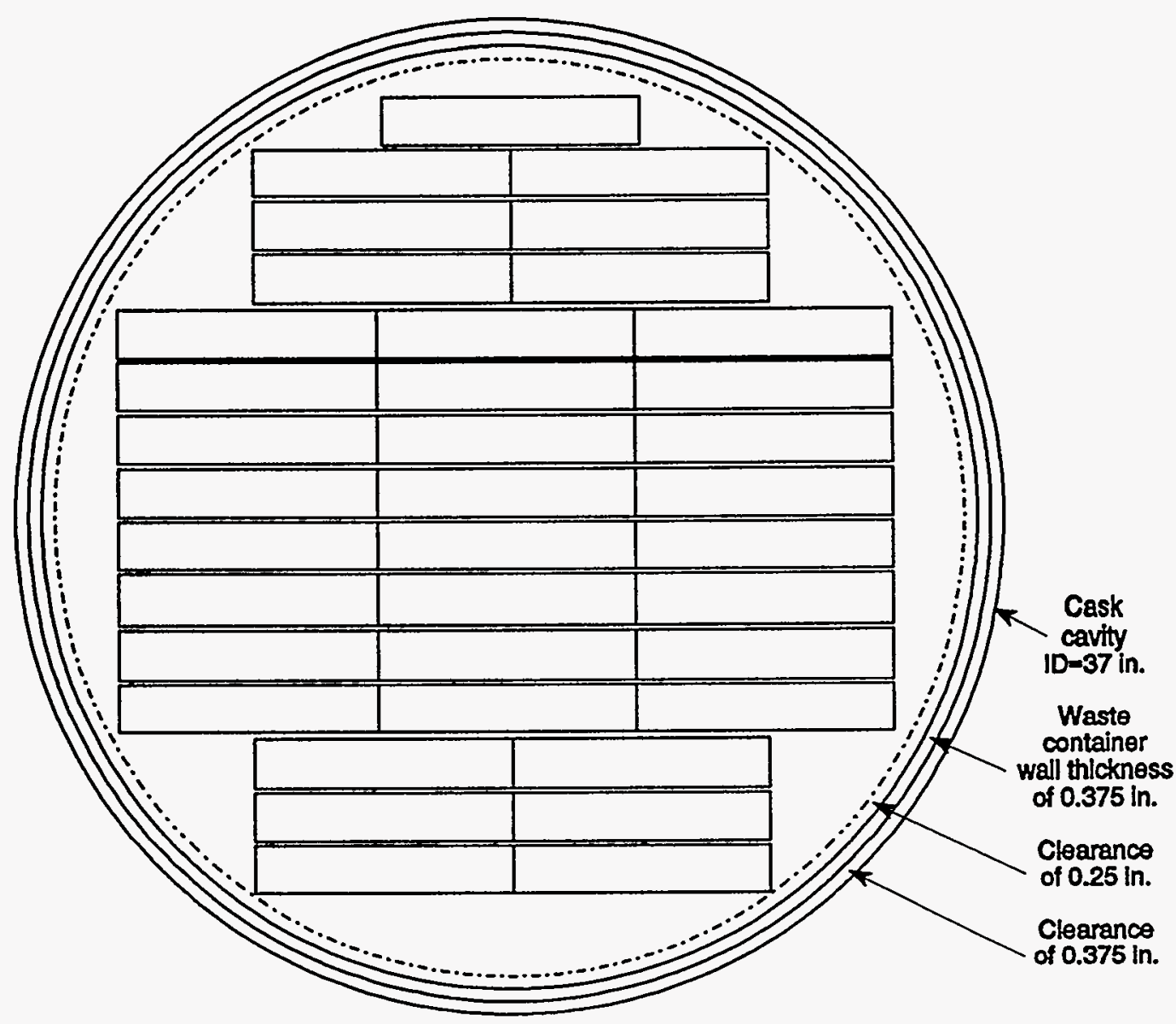

00400178

Figure 4. Arrangement of BWR control rod blades in a cylindrical cross-section waste container.

Example: Model IF-300 rail cask without basket

Flattened CRB envelope dimensions: $2 \times 10$ in. 
Figure 5 shows an arrangement of boxes that represent the flattened CRBs in the waste container. The $11 \mathrm{CRBs}$ in the container have a displaced volume (not envelope dimension volume) of $6.6 \mathrm{ft}^{3}$. With a waste container outer volume of $29.06 \mathrm{ft}^{3}$, the PE for this size of container is $\mathbf{0 . 2 3}$.

- Model BR-100 rail cask The new design Model BR-100 rail cask has an maximum allowable payload weight of $40,000 \mathrm{lb}$. It has a cylindrical internal cavity of $58.5 \mathrm{in}$. diameter and 180 in. depth. For this study, the basket for spent fuel assemblies is removed and replaced by a new design basket that has a square inscribed in the circular cavity. A square cross-section waste container would be placed into the special basket for transport. The dimensions for these components are presented in Table 11. The outside width of the waste envelope is assumed fixed at $37.75 \mathrm{in}$. The length of the container was fixed at 164 in.

Figure 6 shows an arrangement of boxes that represent the flattened CRBs in the waste container. The $63 \mathrm{CRBs}$ in the container have a displaced volume (not envelope dimension volume) of $37.8 \mathrm{ft}^{3}$. With a waste container outer volume of $144.35 \mathrm{ft}^{3}$, the $\mathrm{PE}$ for this size of container is 0.26 .

From these two results, the low case for the PE for BWR CRBs is 0.25 , or a PF of 4 .

High Case. The evaluation of the high-case PF for CRBs assumes that the velocity limiter on the cold end is not cut off and that the entire CRB unit is disposed of as GTCC LLW. Also, the hot end is not flattened between rollers. The CRB unit, as removed from the reactor, is placed into a square cross-section waste container. The volume of the CRB unit is approximately $0.64 \mathrm{ft}^{3}$. One size of square cross-section waste container is evaluated for the high-case PF. The square cross-section waste container for transport in the Model GA-9 cask is similar to that previously described for the GA-4 cask. The GA-9 cask also has a square cavity of 18 in. on a side, but is 178 in. in length, which accommodates the full length of the CRB unit. 


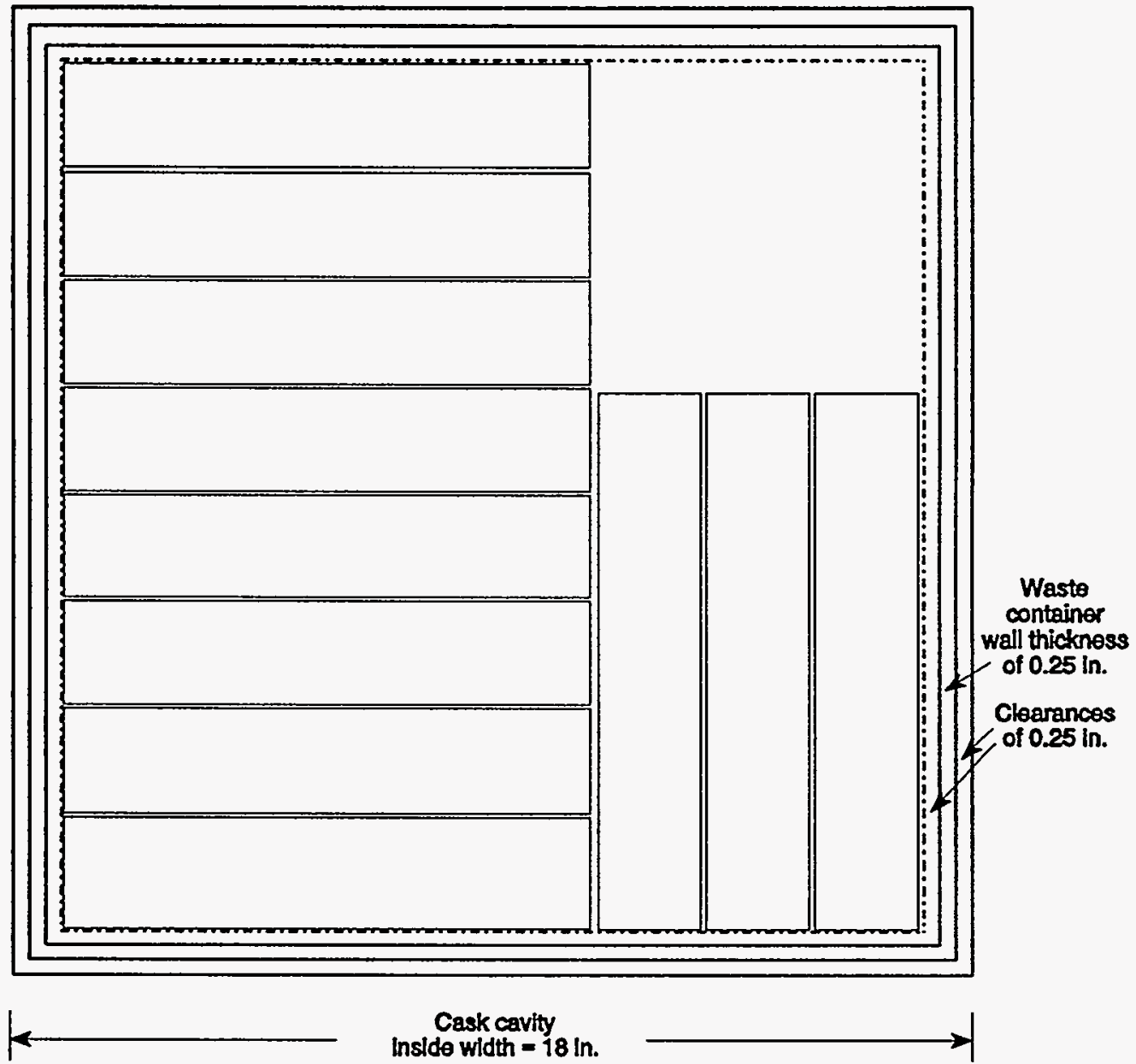

Das0017b

Figure 5. Arrangement of BWR control rod blades in a square cross-section waste container.

Example: Model GA-4 truck cask without basket

Flattened CRB envelope dimensions: $2 \times 10$ in. 


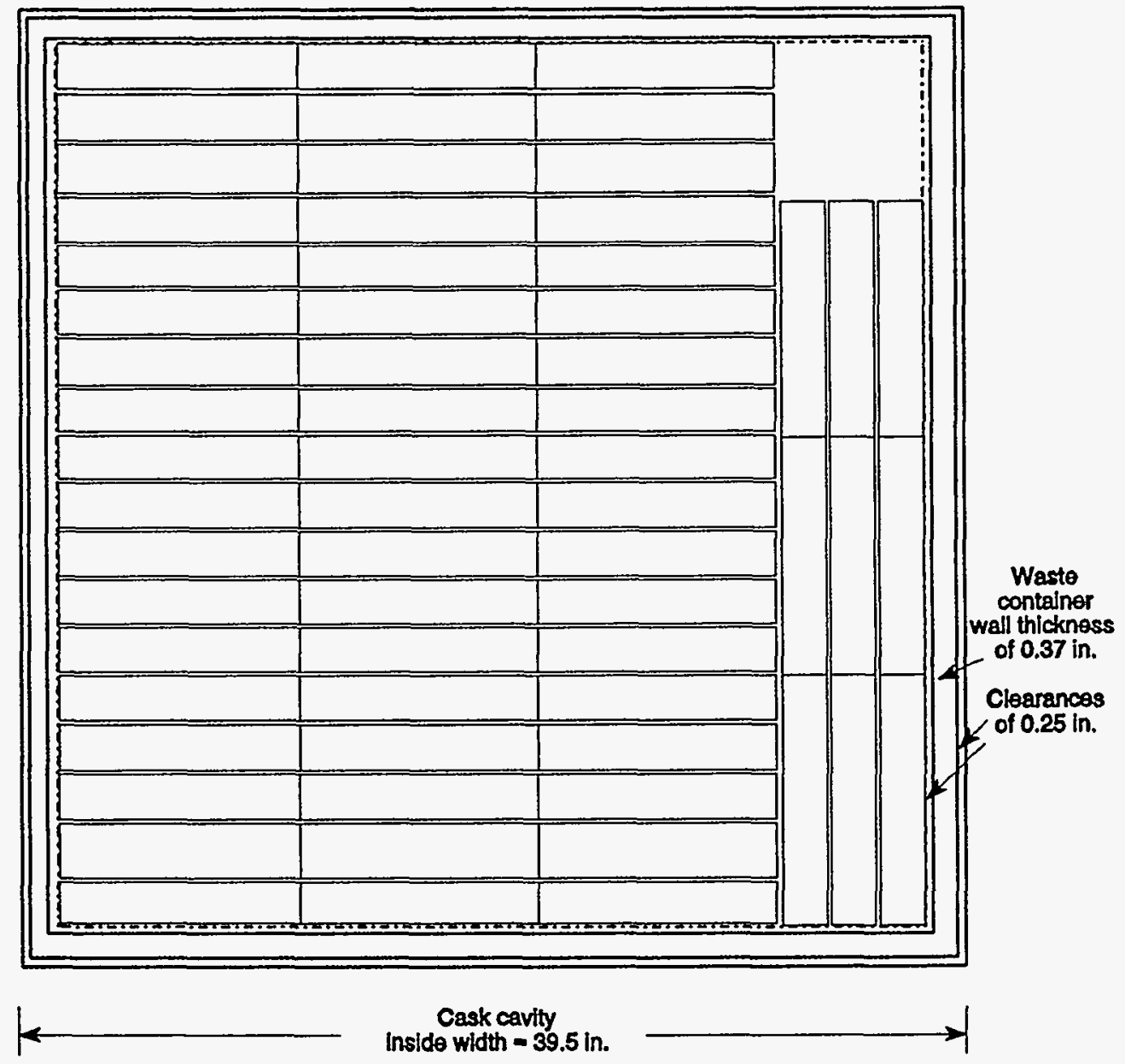

Dasoot7e

Figure 6. Arrangement of BWR control rod blades in a square cross-section waste container.

Example: Model BR-100 rail cask without basket

Flattened CRB envelope dimensions: $2 \times 10 \mathrm{in}$. 
Figure 7 shows an arrangement of CRB units in a waste container. The four CRBs in the container have a displaced volume (not envelope dimension volume) of $2.56 \mathrm{ft}^{3}$. With a waste container outer volume of $31.89 \mathrm{ft}^{3}$, the PE for this size of container is 0.08 . Based on this result and the likelihood that most CRBs would be flattened, the high case PE for CRBs is 0.1, or a PF of 10 .

\subsubsection{BWR and PWR In-Core Instruments}

In-core instruments for both BWR and PWR reactors consist of long, thin-walled metal tubes. The tubes contain neutron detectors that monitor operations of BWR and PWR reactors. An in-core instrument tube is approximately 0.4 to 0.7 in. in diameter, and can be over $100 \mathrm{ft}$ long. An in-core instrument tube is activated by neutrons when part of it is inserted into the core. Since not all of an in-core instrument tube is inserted, there is a hot end and a cold end.

Base, High, and Low Cases. The evaluation of the PFs assumes that the cold end is cut off and disposed of as commercial LLW. The hot end is placed into a square cross-section waste container. The displaced volume of the metal tube is approximately 0.005 to $0.2 \mathrm{ft}^{3}$, depending upon the wall thickness of the metal tube. The small displaced volume and envelope dimensions of the in-core instrument tube relative to the volume of the waste container require rather gross estimates for the base, high, and low case PFs.

The base case PF is estimated to be 5, or a PE of 0.2. This value is, however, no more than about the center of the range for the high and low cases. The high case PF is estimated to be 10 , or a PE of 0.10. The low case PF is estimated to be 3, or a PE of 0.33 . These proposed values consider the following calculations:

- The number of in-core instrument tubes in the smallest size waste container was determined for several sets of variables. The smallest size container is one transported in a spent fuel cask for PWR assemblies as described above. The outside length of the square side of the container is 8.25 in., and the length of the side of the waste envelope is 7.25 in.

- The sets of variables considered the outer diameter (OD) of the in-core instrument tubes, their wall thickness (THK), and the gap between the tubes. The gap represents the volume in a container that cannot be efficiently used because of the difficulty in loading the tubes in a triangular pitch array in a waste container remotely under water. The larger the gap between the tubes, the fewer the number of tubes that the container will hold.

- A PE of 0.34 results from tubes 0.7 in. OD, 0.12 in. THK, with a small gap between the tubes. A total of 108 tubes would be in the container. If the gap increases to 0.2 in. between the tubes, the number of tubes in the container would drop to 64 , and the PE would drop to 0.20 . 


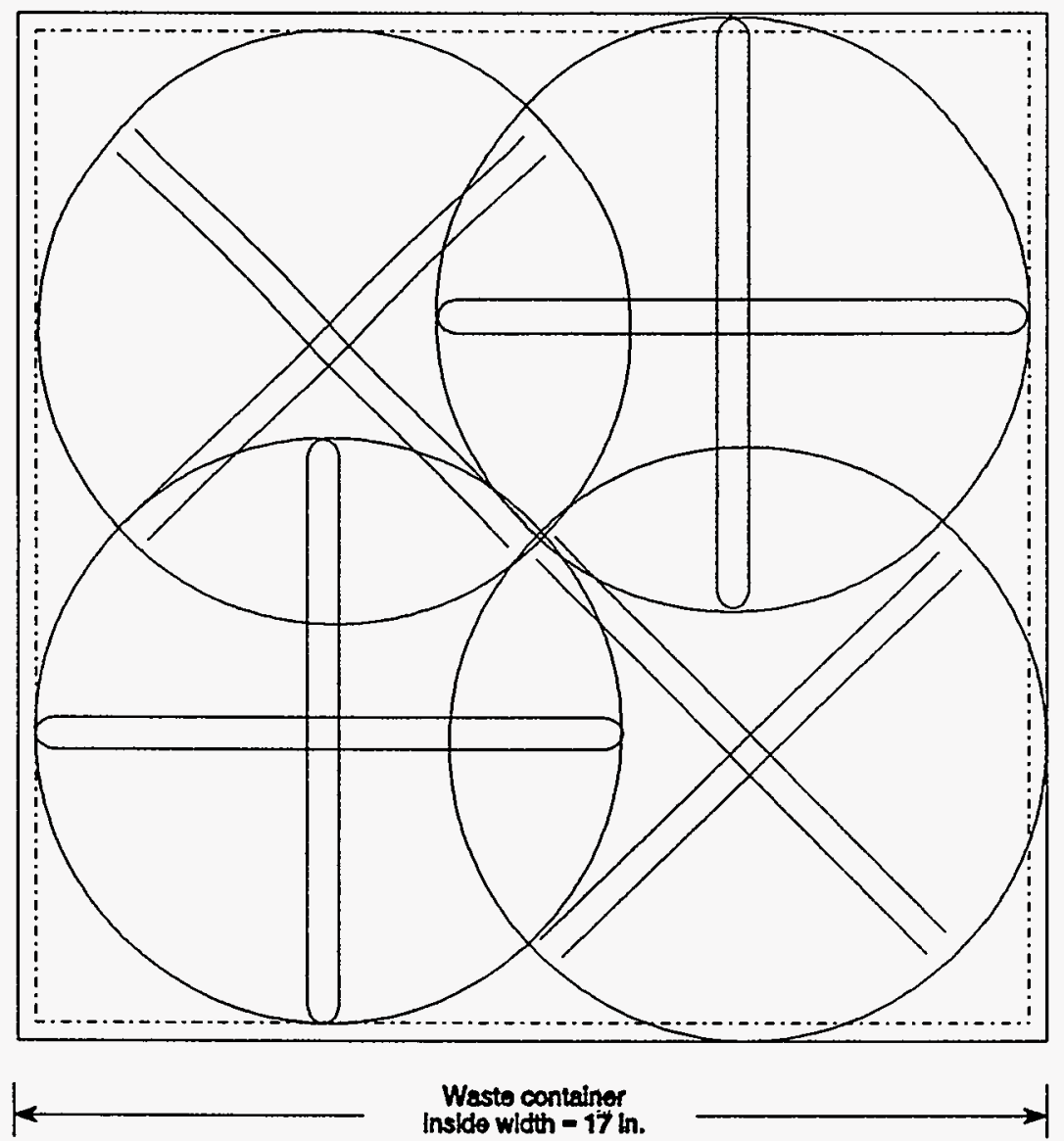

Descoste

Figure 7. Arrangement of BWR control rod blades in a square cross-section waste container.

Example: Model GA-9 truck cask without basket

CRB envelope dimensions: 10 in. diameter 
- A PE of 0.28 results from tubes $0.4 \mathrm{in.} \mathrm{OD,} 0.06 \mathrm{in}$. THK, with a small gap between the tubes. A total of 358 tubes would be in the container. If the gap increases to $0.2 \mathrm{in}$. between the tubes, the number of tubes in the container would drop to 144 , and the PE would drop to 0.11 .

These results show the sensitivity of the PE to the space between the tubes because of the difficulty in loading the tubes remotely. Small changes in assumed wall thickness likewise result in substantial changes in PEs. The three proposed values for the PFs should, however, account for the possible combinations and be reasonable estimates of the PFs for in-core instrument tubes.

\subsubsection{Thimble Plugs}

PWR thimble plugs or orifice rod assemblies resemble PWR control rod assemblies, except that the rods attached to the flat plate or spider that rests on top of a PWR fuel assembly are much shorter than control rods. The rods are only a few inches long. A thimble plug has an envelope dimension of about 6 in. square $\times 11 \mathrm{in}$. high. The thimble plugs are activated by neutrons since they are inserted into the core at the top of a PWR assembly. The entire assembly is activated and considered "hot," although the inconel spring is the activated part that causes a thimble plug to become GTCC LLW.

Base, High, and Low Cases. The evaluation of the PFs assumes that the thimble plug (or orifice rod assembly) is removed from the PWR fuel assembly and disposed of as a unit. The unit is placed into a square cross-section waste container. The displaced volume of the unit is approximately 0.02 to $0.03 \mathrm{ft}^{3}$. The small displaced volume and relatively large envelope dimensions of a thimble plug result in low estimates for the base, high, and low case PFs. The PEs used to determine the PFs were calculated using the following assumptions:

- The number of thimble plugs in a square cross-section waste container for the GA-4 truck cask was determined for several packaging configurations. The outside length of the square side of the container is 17.5 in., and the length of the side of the waste envelope is $16.5 \mathrm{in}$.

- The packaging configurations considered the units both as removed from the fuel assembly, and with the rods flattened to be parallel to the top plate rather than perpendicular to it. The envelope dimensions in the flattened condition are $6 \times 7 \times 12$ in. The unflattened units can either be unnested or nested.

- The unnested configuration is due to the difficulty in loading the units remotely. The unnested configuration approximates a random dropping of units into a waste container.

The above assumptions result in the following PEs:

- A PE of 0.09 results when thimble plugs are stacked into a container standing on end as if in a fuel assembly. The rods in one plug should nest into the coupling of the plug below it and rest on the plate of the lower plug. In this type of nested stacking, there would be 23 layers of four plugs each, or a total of 92 plugs per container. If the 
displaced volume is $0.03 \mathrm{ft}^{3}$, the $\mathrm{PE}$ would be 0.09 . In comparison, if the displaced volume is $0.02 \mathrm{ft}^{3}$, the PE would drop to 0.06 .

- A PE of 0.06 results when thimble plugs are stacked into a container lying horizontally. The rods of one plug would not be nested into another plug. In this type of nested stacking, there would be 27 layers of two plugs each, or a total of 54 plugs per container. If the displaced volume is $0.03 \mathrm{ft}^{3}$, the $\mathrm{PE}$ would be 0.06 . In comparison, if the displaced volume is $0.02 \mathrm{ft}^{3}$, the PE would drop to 0.04 .

- A PE of 0.09 results when thimble plugs are stacked into a container lying horizontally and are nested with the rods from one plug nested into the coupling or rods of another plug. In this type of nested stacking, there would be 23 layers of four plugs each, or a total of 92 plugs per container. If the displaced volume is $0.03 \mathrm{ft}^{3}$, the PE would be 0.09. If the displaced volume is $0.02 \mathrm{ft}^{3}$, the PE would drop to 0.06 .

- A PE of 0.11 results when thimble plugs are flattened and then stacked into a container. The flattened rods are assumed to point up out of the container, and are alternately all against the wall of the container in one layer and in the center of the container in the next layer. In this type of nested stacking, there would be 27 layers of four plugs each, or a total of 108 plugs per container. If the displaced volume is $0.03 \mathrm{ft}^{3}$, the PE would be 0.11 . In comparison, if the displaced volume is $0.02 \mathrm{ft}^{3}$, the $\mathrm{PE}$ would drop to 0.07 .

These results show the lack of sensitivity of the PF to the arrangement of the thimble plugs. The difficulty in loading them remotely will likely cause the PEs to be lower rather than higher. The three proposed values should, however, account for the possible random or stacking configurations and be reasonable estimates of the PFs for thimble plugs.

These assumptions and calculations result in a base case estimated $\mathrm{PF}$ for thimble plugs of 20 , or a PE of 0.05 . This value is, however, no more than about the center of the range for the high and low cases. The high case PF is estimated to be 30 , or a PE of 0.03 . The low case PF is estimated to be 10 , or a PE of 0.1 .

\subsubsection{PWR Primary Sources}

A PWR primary source is a neutron source material located in two rods in a burnable poison rod assembly. A burnable poison rod assembly without a primary source is not GTCC LLW. The rods containing a primary source can be cut from the assembly and then constitute a very small volume of as-generated GTCC LLW. With a displaced volume from 0.002 to $0.016 \mathrm{ft}^{3}$ per rod and only a few rods per reactor, the packaged volume would be very large if the rods are placed into any of the previously described waste containers by themselves. Primary rods are the one waste type that does not warrant a waste-type-specific PF. These items should be mixed into waste containers with other types of GTCC LLW. For purposes of the model to predict packaged volumes, a PF of 1 should be used for the base, high, and low cases. This value will ensure that primary sources are not ignored as a specific waste type. Also, the small value of the unpackaged volumes times a PF of 1 will result in a realistically small contribution for this waste type in comparison to the other activated metal components. 


\section{PACKAGING FACTORS FOR SEALED SOURCES}

This section describes the PFs for GTCC LLW sealed source material. The principal reference for the data used to calculate the packaging factors presented in this section is Characterization of Greater-Than-Class C Low-Level Radioactive Waste Sealed Sources, (DOE/LLW-163) Volumes 1 and 2. Volume 1 describes the data collected from surveys of specific licensees who hold potential sealed sources with activities that exceed Class $C$ limits. These sources are referred to as potential GTCC LLW sealed sources. The data were used to estimate the total number, volume, and activity of potential GTCC sealed sources. Volume 2 reports on the characterization and future production of potential GTCC sealed sources held by specific licensees. The data were entered into a database and used to determine low, base, and high case packaged storage and disposal volumes for potential GTCC sealed sources, which DOE may receive for storage or disposal. The low case and high case volumes are the lower and upper limits of the projections made in the base case volume projections.

\subsection{Background}

Previous estimates of PFs for sealed sources were based on consolidation of sealed sources. For this study, the disposal low case still assumes that maximum consolidation will take place $(P F=2)$, and uses the sealed source volume estimates given in Reference 1 . However, it was recognized that the results of this method are greatly impacted by volumes assumed for the individual sealed sources. Since actual sealed source volumes can vary greatly, the disposal base and high cases use a method that is not sensitive to those assumed volumes. Instead, they assume limits on the total activity that will be placed in a common shielded container. PFs are then backcalculated to provide insight on the resulting volume increases.

In addition to the disposal PFs, a separate storage PF is calculated based on the estimated size of the container in which the source would be placed for shipment and storage at an interim facility to await final disposal. In the storage packaging scenario, this study assumes that the sources remain and are stored within their shipping containers until they are removed and placed in a disposal container.

\subsection{Types, Quantities, and Unpackaged Volumes of Potential GTCC LLW Sealed Sources}

Sealed sources commonly used by specific licensees can be grouped into several device types:

- Calibration sources

- Medical sources

- Well logging sources

- $\quad$ Portable gauge sources

- Irradiation sources 
- Fixed gauge sources

- General neutron sources

- $\quad$ X-ray fluorescence sources

- $\quad$ Other sources (including radiography and nuclear batteries).

Table 10 shows the estimated number, unpackaged volume, and activity of GTCC sealed sources held by specific licensees in 1993 for the low, base, and high cases by principal use/device type. These numbers reflect the totals that will be GTCC after those sources that can be disposed of as LLW have been disposed of by concentration averaging (see Appendix E-5). It is important to note that each device type may include sealed sources with several different radionuclides of varying activity.

\subsection{Storage and Disposal Packaging Scenarios}

The current scenarios for the handling of sealed sources are based on two stages. Stage one, packaging for storage, assumes that sealed sources will be shipped in their respective transport containers to a storage facility to await final disposal or recycling. Sources would remain within their transport containers for storage at the interim storage facility. The PF for storage is the ratio of the volume of a transport container to the unpackaged volume of the individual source. Table 11 shows the average size of the transport container for each device type.

Stage two, packaging for disposal, assumes that sealed sources will be shipped from the licensee or storage facility to a final disposal facility. This scenario assumes that at the final disposal facility, the source will be removed from its device or container and consolidated with other similar sources within a shielded 55-gal drum. The sources would be consolidated by device type or principal radionuclide activity. The PF for disposal is the ratio of the volume of a shielded 55-gal drum to the volume of sources that could be placed into that drum. A 55-gal drum was chosen for this study because it is a commonly used waste container.

The sealed source low case disposal packaged volume is determined by the volume capacity of the waste container. The base and high cases assume that activity limits will determine the number of sources placed in a waste container. The basis for the activity limit is the estimate of the total activity and type of radiation (i.e., alpha/beta versus gamma/neutron) that could be placed in a specially shielded drum and allow the drum to be contact-handled. Attachment 1 shows a diagram of such a possible container.

\subsection{Low, Base, and High Case PFs for Sealed Sources}

The storage PFs for sealed sources are the ratio of the transport container volume shown in Table 11 to the unpackaged volume of the sealed source when it is removed from the particular device. Since the volumes of the transport containers are fairly well known, the storage PFs will be the same in the low, base, and high cases. 
The number of sources that can be placed in a drum for base and high case disposal is dependent on the principal radionuclide and the corresponding activity. For example, more alpha- and beta-emitting sources could be placed in a drum than gamma- or neutron-emitting sources because of the highly penetrating nature of the gamma rays and neutrons. The gamma rays and neutrons would need more shielding for the drum to be contact-handled, leaving less volume for the actual sources. In the base and high disposal cases, it is assumed that the activity limits for the drum would be reached before any volume restrictions would be realized. The disposal PF is calculated by taking the total packaged-for-disposal volume and dividing it by the total volume of the unpackaged sealed sources that are placed into the disposal container.

Table 12 shows the low, base, and high case PFs calculated by the database for sealed source storage and disposal packaged volumes. Not all of the PFs shown in Table 12 are constants. The sealed source database uses the storage and low case disposal PFs as constants to make volume projections for the storage and low cases. However, the database uses the assumptions (discussed in the previous sections) to calculate the number and volume of the containers needed to package the sources for the base and high cases. From these base and high case volumes, the database then determines the base and high case disposal PFs. Any changes to the assumptions, or to the numbers, activities, and types of sources, will change the total packaged volume and the PFs for the base and high cases. The base and high case disposal PFs shown in Table 12 are included to give the reader a representation of the packaged volume increase for each device type.

The low, base, and high case disposal PFs were calculated based on the assumptions explained in the following sections.

\subsubsection{Low Case Disposal PFs for Sealed Sources}

In the disposal low case, all sealed sources will be removed from their respective devices and loaded into high-level waste canisters, or their equivalent, in their smallest configuration. The PF in the low case will be primarily influenced by the void fraction created when loading the canister. This case assumes that the maximum packaging efficiency will be obtained when packing the individual sources into the canister and the maximum void fraction will be 45 to $50 \%$ of the total. The PF for the low case is the inverse ratio of the void fraction, or $1 / 0.5=2$ for all device types. This PF in the low case is expected to be the same for all source and device types.

\subsubsection{Base Case Disposal PFs for Sealed Sources}

The following assumptions are used to calculate base case disposal PFs for sealed sources:

- $\quad$ All sealed sources will be removed from their respective devices and consolidated into shielded 55-gal drums. A diagram of a possible drum design with the inner shielded containers is found in Attachment 1 of this document.

- $\quad$ Sources will be consolidated by device type or radionuclide.

- The total number of sources that can be consolidated in the disposal container will be activity-dependent in order for the drum to be contact-handled. Any number with a total activity to $500 \mathrm{Ci}$ of alpha/beta-emitting sources or low-activity gamma/neutron- 
emitting sources can be consolidated within a disposal container, whereas only five gamma/neutron-emitting sources with an activity of over $30 \mathrm{mCi}$ each can be placed within a disposal container. To provide extra shielding, each gamma source will be placed in its own inner shielded container before being placed in the disposal container.

The database sorts the individual sources within each device type by radionuclide and activity. The database calculates how many alpha/beta and gamma sources can be placed into an individual drum for each radionuclide type using the above-described limits. The database then calculates a total packaged volume for each device type and individual PFs for each device and radionuclide type.

\subsubsection{High Case Disposal PFs for Sealed Sources}

The disposal high case is the same as for the base case, except that a smaller activity limit per drum $(100 \mathrm{Ci})$ is assumed. The smaller activity limit was chosen to provide a margin of safety to ensure that the drums containing the sources could be contact-handled. In addition, only three gamma/neutron-emitting sources with an activity over $30 \mathrm{mCi}$ each could be placed in a container. These limits are used by the database to calculate a disposal packaged volume for the high case. 


\section{PACKAGING FACTORS FOR ALL OTHER GTCC LLW}

Packaging for the following types of GTCC LLW is described in this section:

- Decontamination resins

- Cartridge filters

- Aqueous liquids

- $\quad$ Solidified liquids

- Generic.

\subsection{Decontamination Resins}

The two principal sources of decontamination resins include those generated in purification demineralizers for PWR and BWR reactor coolant systems and processing resins for major system and component decontamination solutions. The reactor coolant system purification resins are not normally GTCC LLW. However, if significant levels of failed fuel exist and resins systems are operated until resin exchange capacity is exhausted, then GTCC LLW resins are possible.

Normally, these resin systems are replaced because of high differential pressure or high radiation fields, which normally preclude this as GTCC LLW.

The other principal source of GTCC LLW ion-exchange resins is from processing highly concentrated chemical decontamination solutions. These solutions contain oxidizers and chelating agents that readily remove the activated corrosion products (e.g., $\mathrm{Ni}-58$ and $\mathrm{Nb}-94$ ) from the surface oxides of the metals. The resins act as a concentration mechanism to highly concentrate these relatively long-lived corrosion products, and may become GTCC LLW.

In determining the packaging scenarios and PFs, the following assumptions are considered valid. First, economic incentives will cause generators to maximize volume reduction technologies once it is concluded that the ion-exchange resins are GTCC LLW. Secondly, operational constraints on maximum concentration limits, capacities, and transport packages (Type B) will not influence loading decisions. Thirdly, the packaging scenario will be directly influenced by the treatment method and any associated volume reduction, which will provide greater or lesser package loading efficiency. The following represents the best reasonable estimate of packaging scenarios and factors for spent resins.

\subsubsection{Packaging Factors for Spent Resins (Base, High, and Low Case)}

Waste generators are normally expected to minimize processing and handling of GTCC LLW spent resins in the most cost-efficient manner. The primary requirement for transporting and receiving wet solids, which is consistent with current requirements, would be to dewater the resins and load them into a high-integrity container (HIC). This effort would only require a sluicing system and dewatering system, with minimal requirements at the generator site. Typically, 
this is done with most resin operations identified in the industry. The loading into a HIC satisfies most isolation and stabilization requirements, and should be suitable for DOE acceptance. The loading efficiencies of this type of operation are only influenced by the resins' packaging efficiency and are not affected by the size of the container. The void fraction for small spherical bead resin is approximately 40 to $50 \%$. Since the volume of resins identified in the source projection studies included the void volumes, a base case projection for spent resins was assumed to be dewatered resins with a volume packaging equivalent to unity.

$$
\mathrm{PF}_{\text {Base Case }}=1 \text { (dewatered resins) }
$$

The high case scenario assumed that requirements for stabilizing the resins other than in a HIC would be imposed. Options for stabilizing the material with no volume reduction could include cementation or solidification by encapsulation with polymer materials. The technology for organic encapsulation typically shows no volume change relative to the dewatered resin volume. For cementation, the typical volume ratio of resins to cement ranges from 1:1 to 1:0.6. A reasonable high case scenario for expected PFs would be a solidified resin matrix with a volume increase of 2 .

$$
\mathrm{PF}_{\text {High Case }}=2 \text { (dewatered and solidified resins) }
$$

The low case scenario assumes that substantial economic incentives exist to maximize volume reduction. This scenario concluded that the latest technology would be used to sinter the resins with compaction to a volume reduction of $10: 1$. The resins would then be stabilized through encapsulation or cementation, with a volume increase to 2:1. The resultant PF for the low case scenario would be a net volume change of 0.2 .

$$
\mathrm{PF}_{\text {Low Case }}=0.2 \text { (sintered and cemented resins) }
$$

\subsection{Cartridge Filters}

The principal sources of filter cartridges are BWR and PWR control rod drive filters, seal water injection and return filters, fuel pool, reactor coolant makeup, and purification system filters. Typically, filters range in size from $0.1 \mathrm{ft}^{3}\left(4 \mathrm{in}\right.$. $\mathrm{OD} \times 12 \mathrm{in}$. long) to $1.0 \mathrm{ft}^{3}(8 \mathrm{in}$. OD $\times$ $3 \mathrm{ft}$ long). The predominant radionuclide contaminants found from activated metals in cartridge filters are $\mathrm{C}-14, \mathrm{Nb}-94$, and $\mathrm{Tc}-99$. In addition, some transuranic contaminants are found (Cm-242, Pu-241, and other traces of transuranics). Cartridge filters generally contain metal endcaps for stability, which are retained with the discarded filter.

\subsubsection{Packaging Factors for Cartridge Filters (Base, High, and Low Case)}

Generator decisions on packaging and transport to DOE will be influenced by processes with the least cost and impact for volume reduction, handling, and packaging. Cartridge filters do not require any special processing for collection and handling other than dose and contamination control. Consistent with current practices, it is reasonable to conclude that spent filters would be dewatered and packaged in HICs with no consideration of volume reduction. Currently, highly contaminated filters (i.e., Class B or C) are randomly placed in open HICs with flange closure lids. The loading efficiency with these various-sized filters in a relatively larger HIC would be 
expected to range from .25 to 0.5 . This scenario is considered the most likely (base case) because of minimal cost and accepted practice for storage and disposal.

$$
\mathrm{PF}_{\text {Base Case }}=2 \text { (dewatered filters/no volume reduction) }
$$

In the high case scenario, where encapsulation (i.e., cementation or equivalent) might be a requirement, it was assumed that the encapsulation material would be used to fill the voids created by the filter cartridges. The packaging efficiency for this scenario is the worst case, $(0.25)$, with a PF of 4.

$$
\mathrm{PF}_{\text {High Case }}=4 \text { (encapsulated filters/no volume reduction) }
$$

In the low case scenario, it is assumed that significant economic incentive exists for the generator to look at available technologies and service organizations to reduce volume and package the waste filters. Current technology services available include shredding and encapsulation. A volume reduction of $10: 1$ or greater is expected.

$$
\mathrm{PF}_{\text {Low Case }}=0.1 \text { (shredding and encapsulation) }
$$

\subsection{Aqueous Liquids}

The primary sources of GTCC aqueous liquids include americium salts and americium oxide dissolved in nitric acid and hydrofluoric acid. These liquids generally contain both transuranic and activated fission product components. The treatment and processing considerations for transportation, storage, and disposal usually require solution neutralization and solidification. The transuranic activities in these liquids influence their GTCC LLW classifications. Since GTCC LLW liquids cannot be easily transported, the generators will usually use best available technologies for volume reduction and stabilization. These technologies and treatment services include ion-exchange processing (similar to treatment of decontamination solutions), evaporation, and direct solidification. These aqueous liquids, after $\mathrm{pH}$ adjustment (neutralization), are readily amenable to all demonstrated treatment technologies.

\subsubsection{Packaging Factors for Aqueous Liquids (Base, High, and Low Case)}

One current method for concentrating and stabilizing the aqueous liquids is the use of ionexchange resins. These resins could be processed as discussed in Section 4.1. Based on the expected high dissolved salt content and the associated resin capacity, the volume reduction in this process would not be expected to be much greater than 10:1. Because of the relatively high concentration loading of transuranics and salts, it may be expected that these resins would be placed into a HIC or solidified by cementation. The volume increase with cementation is approximately 1.6 , and the overall processing and packaging volume reduction would be expected to be approximately 0.2 . The container used to solidify the material would be the same as the disposal container and, therefore, the PF would be 0.2 .

$$
\mathrm{PF}_{\text {Base Case }}=0.2 \text { (ion-exchange/solidified liquids) }
$$


The high case scenario for processing liquids assumes that a base solution neutralization step will be required, which could double the volume of the waste liquid before further processing. This step would then be followed by a cementation process, which could increase the volume by 1.6. The net increase in volume for the high volume scenario is $3: 1$.

$$
\mathrm{PF}_{\text {High Case }}=3.0 \quad(\mathrm{pH} \text { adjusted/solidified })
$$

The low case scenario assumes that the liquids will be evaporated to near-dryness and then solidified in cement. Because the acid and dissolved salt content is relatively high (1 to 2 wt\%), the concentration factor for evaporation would be less than 100 . The cementation step would increase the volume, with a net volume reduction of approximately 10 .

$$
\mathrm{PF}_{\text {Low Case }}=0.1 \quad \text { (evaporation/solidified liquids) }
$$

\subsection{Solidified Liquids}

The sources of GTCC LLW solidified liquids include transuranic bearing solids from fuel fabrication facilities and highly concentrated process liquids from BWR and PWR facilities. It is assumed that no additional requirement exists for processing this material. Additionally, no special restrictions exist for packaging, transportation, storage, and disposal of this material. The physical form of this material is considered to be as a solidified monolith or as solid granular material.

\subsubsection{Packaging Factors for Solidified Liquids (Base, High, and Low Case)}

Since this material exists in a solid form, there may be no economic incentive to further process and reduce the volume of this waste form. The most probable packaging and handling scenario would be to leave this material in the existing transport package, or transfer the material into disposal containers and load it to the maximum extent practical. The material would be expected to fill each container with minimal voids and loading inefficiencies. The packaging volume would be similar to the source projection volume.

$$
\mathrm{PF}_{\text {Base Case }}=1 \quad \text { (dry with no further processing) }
$$

The high case scenario assumes that the solid form of material will be encapsulated because of stabilization requirements. Consistent with previously used methods, this could include cementation, with a volume increase factor of 1.6. The waste form would be formed in the storage, transport, and disposal container with minimal voids.

$$
\mathrm{PF}_{\text {High Case }}=1.6 \text { (no volume reduction/encapsulation) }
$$

The low case scenario assumes the use of the best available and demonstrated technology. It is also assumed that the solid material is not amenable to incineration or similar processes. The low case scenario considers the vitrification or melting of solidified liquids, with a potential volume reduction of $20 \%$. The waste form would be formed in the storage and disposal container, with optimum packaging efficiency. 


$$
\mathrm{PF}_{\text {Low Case }}=0.8 \quad \text { (vitrification) }
$$

\section{5 "Generic" Other GTCC LLW}

The previous sections calculate PFs for decontamination resins, cartridge filters, and aqueous and solidified liquids. This section discusses all remaining GTCC LLW in a general way, based on broad assumptions.

A generic base case for a PF for all other GTCC LLW is a factor of 1.0. This value reflects the uncertainty in the volume reduction technologies that can be used for GTCC LLW and the uncertainty in the amounts of the different types of materials that will be generated. A reasonable assumption appears to be that the volume decrease from compaction, incineration, and other volume reduction technologies will offset the volume increase from packaging noncompactible materials into waste containers. With this assumption, the gains from volume reduction technologies would offset the historical increase in the overall volume of waste just from the packaging of the waste.

The generic low value for the PF for all other GTCC LLW is 0.5 , or a prediction that a net reduction will occur from the amount generated to the amount disposed. This value reflects the significant advances in supercompaction and radioactive waste incineration that have recently become available for LLW treatment in the United States. With volume reduction factors of 300 to 1 for incineration and 10 to 1 for supercompaction, treatment of significant amounts of the GTCC LLW by these methods would bring the PF down considerably. The proposed value reflects that these new technologies will be available and used to some extent by the GTCC LLW generators.

The generic high value for the PF for all other GTCC LLW is expected to be 1.5 , or a packaging efficiency of 0.67 . This value represents an inability to use volume reduction technologies to a significant extent for GTCC LLW because of the radionuclide concentrations that make the waste GTCC LLW to begin with. Commercial treatment centers may be unwilling to allow treatment because of the potential for significant contamination of expensive equipment. Also, GTCC LLW generators may not have the volume of GTCC LLW to justify installation of volume-reduction equipment. The proposed value reflects the unique nature of this waste and the potential difficulty in processing it economically. 


\section{SUMMARY}

This report estimated PFs for several waste types that are potential GTCC LLW. The PF is defined as the volume of a GTCC LLW packaging container divided by the as-generated or "unpackaged" volume of the waste loaded into the container. PFs for the following types of waste were calculated:

- Activated metal GTCC LLW

- $\quad$ Sealed source GTCC LLW

- Other GTCC LLW.

Activated metals can be grouped into two categories: decommissioning and operations. The largest volumes of activated metal components are from decommissioning, and consist of the PWR and BWR core shrouds and support plates, and the PWR core barrels. The activated metal operations components are much smaller in volume and include BWR control rod blades, PWR and BWR in-core instrument strings, and PWR primary sources. The calculation models used to determine the PEs and PFs assumed that the activated metals would be cut and sized to fit into the containers in a reasonably efficient manner. This was considered to be the base case scenario. The low case scenario assumes a higher PE and lower PF because of more efficient packaging techniques. The high case scenario assumes a smaller $\mathrm{PE}$ and greater $\mathrm{PF}$ because shipping cask weight constraints might limit the quantity of GTCC LLW components placed in any one container. The low and high cases are the best reasonable lower and upper limits of the base case.

Activity constraints on a loaded waste container were not factored into this study; it was assumed that the generator will select a shipping cask and copackage the GTCC LLW in such a way that activity constraints can be met and are not limiting.

Volume constraints are also not considered limiting for large activated metal components. Instead, weight limits of spent fuel shipping casks are reached before volume limits are. Conditions such as remote handling, poor visibility, and cutting of the LAMC into variable shapes and sizes with rough edges make it very difficult to efficiently pack the large activated metal waste. This study therefore does not include the volume-constrained packing models and some of the weight-constrained models that were considered in the 1991 study.

The PFs for sealed sources are based on two separate packaging scenarios:

- Packaging for storage, or the storage PF

- Packaging for disposal, or the disposal PF.

The storage packaging scenario assumes that sealed sources will remain within their respective devices and be packaged in an appropriate shipping container for shipment to a storage facility to await disposal. The sealed source would be stored as shipped. The base case storage $\mathrm{PF}$ is the total volume of the average transport container divided by the average unpackaged volume of the individual sealed source for that device type. PFs will vary depending upon device 
type and transport container dimensions. Since the average dimensions for each container are documented for each device type, the low and high case PFs for sealed sources are the same as the base case PF.

The disposal packaging scenario assumes that sources will be removed from their individual devices and placed in shielded disposal containers. The low case assumes that sources will be packaged in the most efficient manner and will be constrained based on volume, with a PF of 2 . The base and high cases assume that the sources will be loaded into specially shielded 55-gal drums. The total volume of sources placed within a drum would be limited by the total activity that a drum could hold and still be contact-handled. The activity limit for the base case is $500 \mathrm{Ci} / \mathrm{drum}$, and the limit for the high case is $100 \mathrm{Ci} / \mathrm{drum}$ for most sources. However, for the high energy and activity gamma/neutron-emitting sources, a maximum of five sources could be placed in a drum in the base case, and a maximum of three could be placed in a drum in the high case. These activity limits are the best reasonable estimates of the total activity that could be placed in a specially shielded drum and still be contact-handled. The base and high case disposal PFs for sealed sources will vary for the different device types because of the variety of radionuclides and activities.

The other types of GTCC LLW for which PFs were considered in this report include:

- Decontamination resins

- $\quad$ Cartridge filters

- Aqueous liquids

- $\quad$ Solidified liquids

- $\quad$ "Generic" GTCC LLW.

Decontamination resins are generated primarily by nuclear utilities. These resins include routine spent resins from plant systems and processing resins from special plant system decontaminations. In determining the packaging scenarios and related PFs for decontamination resins, the economic, regulatory, and operational constraints were considered to include such factors as the use of possible volume reduction technologies, packaging limits and constraints, and treatment technologies. The results were a base case PF that assumed that the resin volume would be dewatered and placed in a HIC, a low case PF that assumed economic incentives to maximize volume reduction through the use of treatment technologies, and a high case PF that assumed that requirements for the final disposal of the resin would include the addition of a stabilization media, such as cement, that would be considered part of the waste volume.

Cartridge filters are principally generated by nuclear utility operations. In determining the packaging scenarios and related PFs for cartridge filters, the economic, regulatory, and operational constraints were considered to include such factors as the use of volume reduction technologies, packaging limits and constraints, and treatment technologies. The result was a base case PF that assumes that cartridge filters will be dewatered and placed in HICs with no attempt at volume reduction. The low case PF was determined assuming that the filters would be shredded and 
encapsulated to obtain an overall volume reduction. The high case PF was determined assuming that the filters would be encapsulated with no initial volume reduction techniques.

Aqueous liquids can be generated by a number of processes from nuclear utilities, sealed source manufacturing, radioisotope manufacturers, university reactors, fuel reprocessing, and other similar types of operations. In determining the packaging scenarios and related PFs for aqueous liquids, the economic, regulatory, and operational constraints were considered to include such factors as the use of possible volume reduction technologies, packaging limits and constraints, and treatment technologies. The result was a base case PF for aqueous liquids that assumes that the waste will be processed through an ion exchange resin, and that the resin and remaining liquid would be solidified. The high case PF was determined by assuming that the liquid would have to undergo a base solution neutralization step that would double the volume before further processing. The low case PF was determined by assuming that the liquids would be evaporated to near dryness and then solidified in cement.

Solidified liquids are generated from the same types of operations as aqueous liquids. Solidified liquids already exist in solid form and there may be no incentive for further treatment. The most probable packaging scenario would be to leave this material in the existing transport package, or consolidate the material to the maximum extent possible. This approach results in a base case PF that assumes that the waste is already dry and no further processing is performed. The low case PF assumes that some form of treatment, such as vitrification, of this waste is possible to reduce the volume. The high case PF assumes that the volume is increased due to the addition of stabilization media.

"Generic" waste is GTCC LLW from a source other than those previously defined in this report. The generic base case PF assumes that the waste will be packaged in the same volume as it was generated. The low case assumes that a volume reduction could occur through the use of compaction or incineration. The high case assumes that the waste will not be a candidate for volume reduction, and will require the use of special packaging or the addition of stabilization media.

All of the PFs presented in this report were calculated using the best data available to determine the effects of the packaging using the indicated assumptions. These PFs can be applied to similar wastes to determine the possible total volumes of GTCC LLW. A summary of the PFs for all waste forms described in this report is presented in Table 13. A PF of greater than 1 indicates that a total volume increase in that case can be expected for the waste type. A $\mathrm{PF}$ of less than 1 indicates that a total volume reduction is possible in that case for each waste type. 
Table 1. Potential GTCC LLW and generators.

\begin{tabular}{|c|c|}
\hline $\begin{array}{c}\text { Potential } \\
\text { GTCC LLW waste type }\end{array}$ & Generator \\
\hline Activated metals & Nuclear power plants \\
\hline \multicolumn{2}{|l|}{$\begin{array}{l}\text { BWR operations } \\
\text { Control rod blades } \\
\text { In-core instruments }\end{array}$} \\
\hline \multicolumn{2}{|l|}{$\begin{array}{l}\text { PWR operations } \\
\text { Thimble plugs } \\
\text { In-core instruments } \\
\text { Primary sources }\end{array}$} \\
\hline \multicolumn{2}{|l|}{$\begin{array}{l}\text { BWR decommissioning } \\
\text { Core shroud }\end{array}$} \\
\hline \multicolumn{2}{|l|}{$\begin{array}{l}\text { PWR decommissioning } \\
\text { Core shroud } \\
\text { Core barrel }\end{array}$} \\
\hline Sealed sources & Manufacturers and users \\
\hline \multicolumn{2}{|l|}{ All other GTCC LLW } \\
\hline Decontamination resins & Nuclear power plants \\
\hline Cartridge filters & Nuclear power plants \\
\hline Aqueous liquids & Industrial and academic users \\
\hline Solidified liquids & $\begin{array}{l}\text { Fuel testing and burnup evaluation } \\
\text { facilities and industrial users }\end{array}$ \\
\hline Generic & Any generator \\
\hline
\end{tabular}


Table 2. Packaging efficiencies for the TITAN truck cask without'a spent fuel basket (weightconstrained, cylindrical waste containers). ${ }^{a}$

\begin{tabular}{|c|c|c|c|c|c|c|c|}
\hline \multirow[b]{2}{*}{$\begin{array}{c}\text { Case } \\
\text { number }\end{array}$} & \multicolumn{3}{|c|}{ LCB dimensions (in.) } & \multirow[b]{2}{*}{$\begin{array}{l}\text { Packaging } \\
\text { efficiency for } \\
\text { entire LCB }\end{array}$} & \multirow[b]{2}{*}{$\begin{array}{l}\text { Number of waste } \\
\text { containers } \\
\text { needed }\end{array}$} & \multirow[b]{2}{*}{$\begin{array}{l}\text { Packaging } \\
\text { efficiency for a } \\
\text { full waste } \\
\text { container }\end{array}$} & \multirow[b]{2}{*}{$\begin{array}{l}\text { Weight of a full } \\
\text { waste container } \\
\text { (lb) }\end{array}$} \\
\hline & $\begin{array}{c}\text { Outer } \\
\text { diameter }\end{array}$ & $\begin{array}{c}\text { Inner } \\
\text { diameter }\end{array}$ & Thickness & & & & \\
\hline 1 & 153 & 148 & 2.5 & 0.222 & 12 & 0.225 & 6,235 \\
\hline 2 & 152 & 148 & 2 & 0.213 & 10 & 0.225 & 6,235 \\
\hline 3 & 154 & 148 & 3 & 0.214 & 15 & 0.225 & 6,235 \\
\hline 4 & 163 & 158 & 2.5 & 0.219 & 13 & 0.225 & 6,235 \\
\hline 5 & 162 & 158 & 2 & 0.206 & 11 & 0.225 & 6,235 \\
\hline 6 & 164 & 158 & 3 & 0.214 & 16 & 0.225 & 6,235 \\
\hline 7 & 143 & 138 & 2.5 & 0.208 & 12 & 0.225 & 6,235 \\
\hline 8 & 142 & 138 & 2 & 0.221 & 9 & 0.225 & 6,235 \\
\hline 9 & 144 & 138 & 3 & 0.214 & 14 & 0.225 & 6,235 \\
\hline
\end{tabular}

a. Payload weight is maximized up to the $6,235-1 \mathrm{~b}$ limit for the cask. 
Table 3. Dimensions of the Model IF- 300 rail cask with basket removed.

Dimension

Parameter

(in.)

Inside dimensions of cask cavity:

diameter

37.5

depth

180.25

Clearance between inside surface of the

0.375

cask cavity and outside surface of the

waste container

Outside dimensions of the waste container:

Outside diameter

36.75

Overall length

164

Wall thickness of the waste container

0.375

Clearance between the inside surface of

0.25

the waste container and the outside of the

waste envelope

Outside dimensions of the waste envelope:

Diameter

Length

161 
Table 4. Packaging efficiencies for the Model IF-300 rail cask without a spent fuel basket (weight-constrained, cylindrical waste containers). ${ }^{\text {a }}$

\begin{tabular}{|c|c|c|c|c|c|c|c|}
\hline \multirow[b]{2}{*}{$\begin{array}{c}\text { Case } \\
\text { number }\end{array}$} & \multicolumn{3}{|c|}{ LCB dimensions (in.) } & \multirow[b]{2}{*}{$\begin{array}{l}\text { Packaging } \\
\text { efficiency for } \\
\text { entire LCB }\end{array}$} & \multirow[b]{2}{*}{$\begin{array}{l}\text { Number of } \\
\text { waste } \\
\text { containers } \\
\text { needed }\end{array}$} & \multirow[b]{2}{*}{$\begin{array}{l}\text { Packaging } \\
\text { efficiency for a } \\
\text { full waste } \\
\text { container }\end{array}$} & \multirow[b]{2}{*}{$\begin{array}{l}\text { Weight of a full } \\
\text { waste container } \\
\text { (lb) }\end{array}$} \\
\hline & $\begin{array}{c}\text { Outer } \\
\text { diameter }\end{array}$ & $\begin{array}{c}\text { Inner } \\
\text { diameter }\end{array}$ & Thickness & & & & \\
\hline 1 & 153 & 148 & 2.5 & 0.267 & 4 & 0.333 & 21,000 \\
\hline 2 & 152 & 148 & 2 & 0.284 & 3 & 0.333 & 21,000 \\
\hline 3 & 154 & 148 & 3 & 0.321 & 4 & 0.333 & 21,000 \\
\hline 4 & 163 & 158 & 2.5 & 0.285 & 4 & 0.333 & 21,000 \\
\hline 5 & 162 & 158 & 2 & 0.303 & 3 & 0.333 & 21,000 \\
\hline 6 & 164 & 158 & 3 & 0.274 & 5 & 0.333 & 21,000 \\
\hline 7 & 143 & 138 & 2.5 & 0.332 & 3 & 0.333 & 21,000 \\
\hline 8 & 142 & 138 & 2 & 0.265 & 3 & 0.333 & 21,000 \\
\hline 9 & 144 & 138 & 3 & 0.300 & 4 & 0.333 & 21,000 \\
\hline
\end{tabular}

a. Payload weight is maximized up to the $21,000-1 b$ limit for the cask: 
Table 5. Packaging efficiencies for the Model 125-B rail cask without an inner containment vessel (weight-constrained, cylindrical waste containers). ${ }^{a}$

\begin{tabular}{|c|c|c|c|c|c|c|c|}
\hline \multirow[b]{2}{*}{$\begin{array}{c}\text { Case } \\
\text { number }\end{array}$} & \multicolumn{3}{|c|}{ LCB dimensions (in.) } & \multirow[b]{2}{*}{$\begin{array}{l}\text { Packaging } \\
\text { efficiency for } \\
\text { entire LCB }\end{array}$} & \multirow[b]{2}{*}{$\begin{array}{c}\text { Number of waste } \\
\text { containers } \\
\text { needed }\end{array}$} & \multirow{2}{*}{$\begin{array}{l}\text { Packaging } \\
\text { efficiency for } \\
\text { a full waste } \\
\text { container }\end{array}$} & \multirow[b]{2}{*}{$\begin{array}{l}\text { Weight of a full } \\
\text { waste container } \\
\text { (lb) }\end{array}$} \\
\hline & $\begin{array}{c}\text { Outer } \\
\text { diameter }\end{array}$ & $\begin{array}{c}\text { Inner } \\
\text { diameter }\end{array}$ & Thickness & & & & \\
\hline 1 & 153 & 148 & 2.5 & 0.283 & 2 & 0.527 & 57,565 \\
\hline 2 & 152 & 148 & 2 & 0.451 & 1 & 0.451 & 57,119 \\
\hline 3 & 154 & 148 & 3 & 0.340 & 2 & 0.527 & 57,565 \\
\hline 4 & 163 & 158 & 2.5 & 0.302 & 2 & 0.527 & 57,565 \\
\hline 5 & 162 & 158 & 2 & 0.481 & 1 & 0.481 & 53,043 \\
\hline 6 & 164 & 158 & 3 & 0.363 & 2 & 0.527 & 57,565 \\
\hline 7 & 143 & 138 & 2.5 & 0.264 & 2 & 0.527 & 57,565 \\
\hline 8 & 142 & 138 & 2 & 0.421 & 1 & 0.421 & 47,194 \\
\hline 9 & 144 & 138 & 3 & 0.318 & 2 & 0.527 & 57,565 \\
\hline
\end{tabular}

a. Payload weight is maximized up to the $57,565-\mathrm{lb}$ limit for the cask. 
Table 6. Packaging efficiencies for casks with PWR spent fuel baskets (weight-constrained, square cross-section waste containers). ${ }^{a}$

\begin{tabular}{|c|c|c|c|c|c|c|c|c|c|}
\hline \multirow[b]{2}{*}{$\begin{array}{l}\text { Case } \\
\text { No. }\end{array}$} & \multicolumn{3}{|c|}{ LCB dimensions (in.) } & \multirow[b]{2}{*}{$\begin{array}{c}\text { Packaging } \\
\text { efficiency } \\
\text { for entire } \\
\text { LCB }\end{array}$} & \multirow[b]{2}{*}{$\begin{array}{c}\text { Number } \\
\text { of waste } \\
\text { containers } \\
\text { needed }\end{array}$} & \multirow[b]{2}{*}{$\begin{array}{c}\text { Packaging } \\
\text { efficiency } \\
\text { for a full } \\
\text { waste } \\
\text { container }\end{array}$} & \multirow[b]{2}{*}{$\begin{array}{l}\text { Width of } \\
\text { the side of } \\
\text { a waste } \\
\text { container } \\
\text { (in.) }\end{array}$} & \multirow[b]{2}{*}{$\begin{array}{l}\text { Weight of } \\
\text { a full waste } \\
\text { container } \\
\text { (lb) }\end{array}$} & \multirow[b]{2}{*}{$\begin{array}{l}\text { Number of } \\
\text { sections of } \\
\text { LCB per } \\
\text { full waste } \\
\text { container }\end{array}$} \\
\hline & $\begin{array}{c}\text { Outer } \\
\text { dia. }\end{array}$ & $\begin{array}{c}\text { Inner } \\
\text { dia. }\end{array}$ & Thk. & & & & & & \\
\hline 1 & 153 & 148 & 2.5 & 0.597 & 43 & 0.609 & 6.7 & 1,498 & 2 \\
\hline 2 & 152 & 148 & 2 & 0.469 & 40 & 0.472 & 7 & 1,306 & 2 \\
\hline 3 & 154 & 148 & 3 & 0.350 & 81 & 0.352 & 7 & 1,025 & 1 \\
\hline 4 & 163 & 158 & 2.5 & 0.609 & 45 & 0.610 & 6.7 & 1,499 & 2 \\
\hline 5 & 162 & 158 & 2 & 0.466 & 43 & 0.472 & 7 & 1,307 & 2 \\
\hline 6 & 164 & 158 & 3 & 0.351 & 86 & 0.352 & 7 & 1,026 & 1 \\
\hline 7 & 143 & 138 & 2.5 & 0.600 & 40 & 0.609 & 6.7 & 1,497 & 2 \\
\hline 8 & 142 & 138 & 2 & 0.461 & 38 & 0.471 & 7 & 1,305 & 2 \\
\hline 9 & 144 & 138 & 3 & 0.348 & 76 & 0.351 & 7 & 1,024 & 1 \\
\hline
\end{tabular}

a. Payload weight is maximized up to the 1,515 -lb limit for each cask cavity position. 
Table 7. Packaging efficiencies for all cases sorted in descending order of packaging efficiency for the entire LCB.

\begin{tabular}{|c|c|c|c|c|c|c|c|}
\hline \multirow[b]{2}{*}{$\begin{array}{c}\text { Table } \\
\text { no. }\end{array}$} & \multirow[b]{2}{*}{$\begin{array}{c}\text { Case } \\
\text { no. }\end{array}$} & \multicolumn{3}{|c|}{ LCB dimensions (in.) } & \multirow[b]{2}{*}{$\begin{array}{l}\text { PE for } \\
\text { entire } \\
\text { LCB }\end{array}$} & \multirow{2}{*}{$\begin{array}{c}\text { No. of } \\
\text { waste } \\
\text { containers } \\
\text { needed }\end{array}$} & \multirow[b]{2}{*}{$\begin{array}{l}\text { PE for a } \\
\text { full waste } \\
\text { container }\end{array}$} \\
\hline & & $\begin{array}{c}\text { Outer } \\
\text { dia. }\end{array}$ & $\begin{array}{c}\text { Inner } \\
\text { dia. }\end{array}$ & Thk. & & & \\
\hline 6 & 4 & 163 & 158 & 2.5 & 0.609 & 45 & 0.610 \\
\hline 6 & 7 & 143 & 138 & 2.5 & 0.600 & 40 & 0.609 \\
\hline 6 & 1 & 153 & 148 & 2.5 & 0.597 & 43 & 0.609 \\
\hline 5 & $S$ & 162 & 158 & 2 & 0.481 & 1 & 0.481 \\
\hline 6 & 2 & 152 & 148 & 2 & 0.469 & 40 & 0.472 \\
\hline 6 & 5 & 162 & 158 & 2 & 0.466 & 43 & 0.472 \\
\hline 6 & 8 & 142 & 138 & 2 & 0.461 & 38 & 0.471 \\
\hline 5 & 2 & 152 & 148 & 2 & 0.451 & 1 & 0.451 \\
\hline 5 & 8 & 142 & 138 & 2 & 0.421 & 1 & 0.421 \\
\hline 5 & 6 & 164 & 158 & 3 & 0.363 & 2 & 0.527 \\
\hline 6 & 6 & 164 & 158 & 3 & 0.351 & 86 & 0.352 \\
\hline 6 & 3 & 154 & 148 & 3 & 0.350 & 81 & 0.352 \\
\hline 6 & 9 & 144 & 138 & 3 & 0.348 & 76 & 0.351 \\
\hline 5 & 3 & 154 & 148 & 3 & 0.340 & 2 & 0.527 \\
\hline 4 & 7 & 143 & 138 & 2.5 & 0.332 & 3 & 0.333 \\
\hline 4 & 3 & 154 & 148 & 3 & 0.321 & 4 & 0.333 \\
\hline 5 & 9 & 144 & 138 & 3 & 0.318 & 2 & 0.527 \\
\hline 4 & 5 & 162 & 158 & 2 & 0.303 & 3 & 0.333 \\
\hline 5 & 4 & 163 & 158 & 2.5 & 0.302 & 2 & 0.527 \\
\hline 4 & 9 & 144 & 138 & 3 & 0.300 & 4 & 0.333 \\
\hline 4 & 4 & 163 & 158 & 2.5 & 0.285 & 4 & 0.333 \\
\hline 4 & 2 & 152 & 148 & 2 & 0.284 & 3 & 0.333 \\
\hline 5 & 1 & 153 & 148 & 2.5 & 0.283 & 2 & 0.527 \\
\hline 4 & 6 & 164 & 158 & 3 & 0.274 & 5 & 0.333 \\
\hline 4 & 1 & 153 & 148 & 2.5 & 0.267 & 4 & 0.333 \\
\hline 4 & 8 & 142 & 138 & 2 & 0.265 & 3 & 0.333 \\
\hline
\end{tabular}


Table 7. (continued).

\begin{tabular}{cccccccc}
\hline & & \multicolumn{3}{c}{ LCB dimensions (in.) } & & & \\
\cline { 3 - 5 } $\begin{array}{c}\text { Table } \\
\text { no. }\end{array}$ & $\begin{array}{c}\text { Case } \\
\text { no. }\end{array}$ & $\begin{array}{c}\text { Outer } \\
\text { dia. }\end{array}$ & $\begin{array}{c}\text { Inner } \\
\text { dia. }\end{array}$ & Thk. & $\begin{array}{c}\text { PE for } \\
\text { entire } \\
\text { LCB }\end{array}$ & $\begin{array}{c}\text { No. of } \\
\text { waste } \\
\text { containers } \\
\text { needed }\end{array}$ & $\begin{array}{c}\text { PE for a } \\
\text { full waste } \\
\text { container }\end{array}$ \\
\hline 5 & 7 & 143 & 138 & 2.5 & 0.264 & 2 & 0.527 \\
2 & 1 & 153 & 148 & 2.5 & 0.222 & 12 & 0.225 \\
2 & 8 & 142 & 138 & 2 & 0.221 & 9 & 0.225 \\
2 & 4 & 163 & 158 & 2.5 & 0.219 & 13 & 0.225 \\
2 & 9 & 144 & 138 & 3 & 0.214 & 14 & 0.225 \\
2 & 3 & 154 & 148 & 3 & 0.214 & 15 & 0.225 \\
2 & 6 & 164 & 158 & 3 & 0.214 & 16 & 0.225 \\
2 & 2 & 152 & 148 & 2 & 0.213 & 10 & 0.225 \\
2 & 7 & 143 & 138 & 2.5 & 0.208 & 12 & 0.225 \\
2 & 5 & 162 & 158 & 2 & 0.206 & 11 & 0.225 \\
\hline
\end{tabular}


Table 8. Dimensions of the Model GA-4 truck cask.

\begin{tabular}{lc}
\multicolumn{1}{c}{ Parameter } & $\begin{array}{c}\text { Dimension } \\
\text { (in.) }\end{array}$ \\
\hline $\begin{array}{l}\text { Inside dimensions of cask cavity: } \\
\text { side width } \\
\quad \text { depth }\end{array}$ & 18 \\
$\begin{array}{l}\text { Minimum clearance between inside cask } \\
\text { cavity and outside surfaces of the waste } \\
\text { container }\end{array}$ & 167.25 \\
$\begin{array}{l}\text { Waste container maximum outside width } \\
\text { Waste container outside overall length }\end{array}$ & 0.25 \\
$\begin{array}{l}\text { Waste container wall thickness } \\
\text { Minimum clearance between waste } \\
\text { container and outside of waste envelope } \\
\begin{array}{l}\text { Maximum outside width of the waste } \\
\text { envelope }\end{array}\end{array}$ & 17.5 \\
\begin{tabular}{l} 
Outside length of the waste envelope \\
\hline
\end{tabular} & 0.25 \\
\hline
\end{tabular}


Table 9. Dimensions of the Model BR-100 rail cask with the spent fuel basket replaced by a special square cavity basket.

Dimension

Parameter

(in.)

Inside dimensions of cask cavity: diameter

depth

180

Basket cavity side width

Minimum clearance between inside

0.25

surfaces of the cask basket cavity and

outside surfaces of the waste container

Outside dimensions of the waste container:

Maximum side width

39

Overall length

164

Wall thickness of the waste container

Minimum clearance between the inside

0.25

surfaces of the waste container and the

outside of the waste envelope

Outside dimensions of the waste envelope:

Maximum side width

Length

161 
Table 10. Summary of 1993 inventory of GTCC LLW sealed sources (held by specific licensees) after concentration averaging.

\begin{tabular}{|c|c|c|c|c|c|c|c|c|c|}
\hline & \multicolumn{3}{|c|}{ Number of sources } & \multicolumn{3}{|c|}{ Unpackaged volume $\left(\mathrm{m}^{3}\right)$} & \multicolumn{3}{|c|}{ Activity (Ci) } \\
\hline & Low & Base & High & Low & Base & High & Low & Base & High \\
\hline Calibration & 260 & 613 & 1,010 & 0.0005 & 0.00123 & 0.00201 & 10,800 & 21,400 & 32,800 \\
\hline Medical & 3 & 36 & 54 & 0.00006 & 0.00072 & 0.00108 & 5.0 & 316 & 534 \\
\hline Well logging & 590 & 2,030 & 3,760 & 0.0147 & 0.0508 & 0.0941 & 5,330 & 17,900 & 33,100 \\
\hline $\begin{array}{l}\text { Portable } \\
\text { gauge }\end{array}$ & 27 & 1,572 & 2,240 & 0.00054 & 0.0314 & 0.0448 & 7.0 & 73 & 105 \\
\hline Irradiation & 195 & 284 & 433 & 0.0078 & 0.0114 & 0.0173 & 217,000 & 294,000 & 393,000 \\
\hline Fixed gauge & 328 & 505 & 712 & 0.00098 & 0.00152 & 0.00214 & 835 & 1,100 & 1,510 \\
\hline $\begin{array}{l}\text { General } \\
\text { neutron } \\
\text { applications }\end{array}$ & 209 & 370 & 548 & 0.00418 & 0.0074 & 0.011 & 368 & 750 & 1,180 \\
\hline $\begin{array}{l}\text { X-ray } \\
\text { fluorescence }\end{array}$ & 65 & 152 & 344 & 0.00003 & 0.00008 & 0.00017 & 37 & 63 & 91 \\
\hline Other & 673 & 2,020 & 4,440 & 0.00673 & 0.0202 & 0.0444 & 5.550 & 18,400 & 38,400 \\
\hline TOTAL & 2,350 & 7,582 & 13,541 & 0.03552 & 0.12475 & 0.21700 & 240,000 & 354,002 & 500,000 \\
\hline
\end{tabular}


Table 11. Storage information for GTCC sealed sources (sources will be stored in their transport housing).

\begin{tabular}{|c|c|c|c|c|}
\hline Principal use & $\begin{array}{c}\text { Average volume } \\
\text { of sealed source } \\
\text { transport housing } \\
\left(\mathrm{m}^{3}\right)^{\mathrm{a}}\end{array}$ & $\begin{array}{l}\text { Average weight } \\
\text { of sealed source } \\
\text { transport housing } \\
\text { (lb) }\end{array}$ & Radionuclide $^{b}$ & $\begin{array}{l}\text { Range of } \\
\text { activity }^{b}\end{array}$ \\
\hline Calibration & 0.0017 & 35 & $\begin{array}{l}\text { Cs-137 } \\
\text { Am-241 } \\
\text { Sr-90 }\end{array}$ & $\begin{array}{l}15-450 \mathrm{mCi} \\
1-550 \mathrm{mCi} \\
25-700 \mathrm{mCi}\end{array}$ \\
\hline Medical & 0.0017 & 35 & $\begin{array}{l}\text { Cs-137 } \\
\text { Am-241 }\end{array}$ & $\begin{array}{l}105-400 \mathrm{mCi} \\
12-50 \mathrm{mCi}\end{array}$ \\
\hline Well logging & 0.0764 & 165 & $\begin{array}{l}\text { Cs-137 } \\
\text { Am-241 } \\
\text { Pu-238 }\end{array}$ & $\begin{array}{l}0.1-2 \mathrm{Ci} \\
0.02-20 \mathrm{Ci} \\
5-17 \mathrm{Ci}\end{array}$ \\
\hline $\begin{array}{l}\text { Portable } \\
\text { gauges }\end{array}$ & 0.0566 & 31 & $\begin{array}{l}\text { Cs-137 } \\
\text { Am-241 }\end{array}$ & $\begin{array}{l}10 \mathrm{mCi} \\
40-50 \mathrm{mCi}\end{array}$ \\
\hline Irradiation & 0.0849 & 2,127 & $\begin{array}{l}\text { Cs-137 } \\
\text { Am-241 }\end{array}$ & $\begin{array}{l}0.2-3,264 \mathrm{Ci} \\
0.8-5 \mathrm{Ci}\end{array}$ \\
\hline Fixed gauges & 0.017 & 143 & Cs-137 & $.05-1.5 \mathrm{Ci}$ \\
\hline $\begin{array}{l}\text { General } \\
\text { neutron } \\
\text { applications }\end{array}$ & 0.0764 & 125 & $\begin{array}{l}\text { Am-241 } \\
\text { Pu-239 }\end{array}$ & $\begin{array}{l}100-500 \mathrm{mCi} \\
5 \mathrm{Ci}\end{array}$ \\
\hline $\begin{array}{l}\text { X-ray } \\
\text { fluorescence }\end{array}$ & 0.0419 & 35 & $\begin{array}{l}\text { AM-241 } \\
\text { Cm-244 } \\
\text { Pu-238 }\end{array}$ & $\begin{array}{l}10-100 \mathrm{mCi} \\
30-100 \mathrm{mCi} \\
30-100 \mathrm{mCi}\end{array}$ \\
\hline Other & 0.0198 & 167 & $\begin{array}{l}\text { Cs-137 } \\
\text { Am-241 } \\
\text { Pu-238 } \\
\text { Ni-63 } \\
\text { Tc-99 } \\
\text { Pu-239 } \\
\text { Sr-90 }\end{array}$ & $\begin{array}{l}.020-2.2 \mathrm{Ci} \\
15-30 \mathrm{mCi} \\
2.5-14 \mathrm{Ci} \\
8-20 \mathrm{mCi} \\
0.9-3 \mathrm{Ci} \\
0.1-5 \mathrm{Ci} \\
.003-1.8 \mathrm{Ci}\end{array}$ \\
\hline
\end{tabular}

a. Extracted or interpolated from vendor data.

b. Radionuclide and activity ranges were taken from report DOE/LLW-163. 
Table 12. Storage and disposal PFs for sealed sources.

\begin{tabular}{lrrrr}
\hline & & \multicolumn{3}{c}{ Disposal PFs } \\
\cline { 3 - 5 } \multicolumn{1}{c}{ Device type } & Storage PFs & Low & Base & High \\
\hline Calibration & 840 & 2 & 6,100 & 34,700 \\
Medical & 85 & 2 & 500 & 2,550 \\
Well logging & 3,100 & 2 & 145 & 758 \\
Portable gauge & 2,800 & 2 & 2 & 5 \\
Irradiation & 2,100 & 2 & 1,040 & 1,740 \\
Fixed gauge & 5,600 & 2 & 343 & 1,700 \\
General neutron applications & 3,800 & 2 & 35 & 190 \\
X-ray fluorescence & 80,000 & 2 & 420 & 800 \\
Other & 2,000 & 2 & 510 & 2,600 \\
\hline
\end{tabular}


Table 13. GTCC LLW packaging factors to be used in volume projections.

\begin{tabular}{|c|c|c|c|}
\hline $\begin{array}{c}\text { Potential } \\
\text { GTCC LLW waste type }\end{array}$ & Low.case & Base case & High case \\
\hline \multicolumn{4}{|l|}{ Activated metals } \\
\hline $\begin{array}{l}\text { BWR operations } \\
\text { Control rod blades } \\
\text { In-core instruments }\end{array}$ & $\begin{array}{l}4 \\
3\end{array}$ & $\begin{array}{l}5 \\
5\end{array}$ & $\begin{array}{l}10 \\
10\end{array}$ \\
\hline $\begin{array}{l}\text { PWR operations } \\
\text { Thimble plug assemblies } \\
\text { In-core instruments } \\
\text { Primary sources }\end{array}$ & $\begin{array}{r}10 \\
3 \\
1\end{array}$ & $\begin{array}{r}20 \\
5 \\
1\end{array}$ & $\begin{array}{r}30 \\
10 \\
1\end{array}$ \\
\hline $\begin{array}{l}\text { BWR decommissioning } \\
\text { Core shroud } \\
\text { Top fuel guide }\end{array}$ & $\begin{array}{l}2 \\
2\end{array}$ & $\begin{array}{l}3 \\
3\end{array}$ & $\begin{array}{l}5 \\
5\end{array}$ \\
\hline $\begin{array}{l}\text { PWR decommissioning } \\
\text { Core shroud (baffle) } \\
\text { Core barrel } \\
\text { Lower support plates } \\
\text { Upper support plates }\end{array}$ & $\begin{array}{l}2 \\
2 \\
2 \\
2\end{array}$ & $\begin{array}{l}3 \\
3 \\
3 \\
3\end{array}$ & $\begin{array}{l}5 \\
5 \\
5 \\
5\end{array}$ \\
\hline \multicolumn{4}{|l|}{ Sealed sources } \\
\hline $\begin{array}{l}\text { Storage packaging } \\
\text { Calibration } \\
\text { Medical } \\
\text { Well logging } \\
\text { Portable gauge } \\
\text { Irradiation } \\
\text { Fixed gauge } \\
\text { General neutron applications } \\
\text { X-ray fluorescence } \\
\text { Other }\end{array}$ & $\begin{array}{r}840 \\
85 \\
3,100 \\
2,800 \\
2,100 \\
5,600 \\
3,800 \\
80,000 \\
2,000\end{array}$ & $\begin{array}{r}840 \\
85 \\
3,100 \\
2,800 \\
2,100 \\
5,600 \\
3,800 \\
80,000 \\
2,000\end{array}$ & $\begin{array}{r}840 \\
85 \\
3,100 \\
2,800 \\
2,100 \\
5,600 \\
3,800 \\
80,000 \\
2,000\end{array}$ \\
\hline $\begin{array}{l}\text { Disposal packaging } \\
\text { Calibration } \\
\text { Medical } \\
\text { Well logging } \\
\text { Portable gauge } \\
\text { Irradiation } \\
\text { Fixed gauge } \\
\text { General neutron applications } \\
\text { X-ray fluorescence } \\
\text { Other }\end{array}$ & $\begin{array}{l}2 \\
2 \\
2 \\
2 \\
2 \\
2 \\
2 \\
2 \\
2\end{array}$ & $\begin{array}{r}6,100 \\
500 \\
145 \\
2 \\
1,040 \\
343 \\
35 \\
420 \\
510\end{array}$ & $\begin{array}{r}34,700 \\
2,550 \\
758 \\
5 \\
1,740 \\
1,700 \\
190 \\
800 \\
2,600\end{array}$ \\
\hline \multicolumn{4}{|l|}{ All other GTCC LLW } \\
\hline $\begin{array}{l}\text { Decontamination resins } \\
\text { Cartridge filters } \\
\text { Aqueous liquids } \\
\text { Solidified liquids } \\
\text { "Generic" waste }\end{array}$ & $\begin{array}{l}0.2 \\
0.1 \\
0.1 \\
0.8 \\
0.5\end{array}$ & $\begin{array}{l}1 \\
2 \\
0.2 \\
1 \\
1\end{array}$ & $\begin{array}{l}2 \\
4 \\
3 \\
1.6 \\
1.5\end{array}$ \\
\hline
\end{tabular}




\section{REFERENCES}

1. Gerald Harris, Characterization of Greater-Than-Class C Low-Level Radioactive Waste Sealed Sources, Volumes 1, 2, and 3, DOE/LLW-163, September 1994. 


\section{Attachment 1}

\section{Description of 55-Gal Drum for Sealed Source/Device Disposal}

(Design Concepts by Bill Walker, Troxler Electronics, Inc., 1991) 


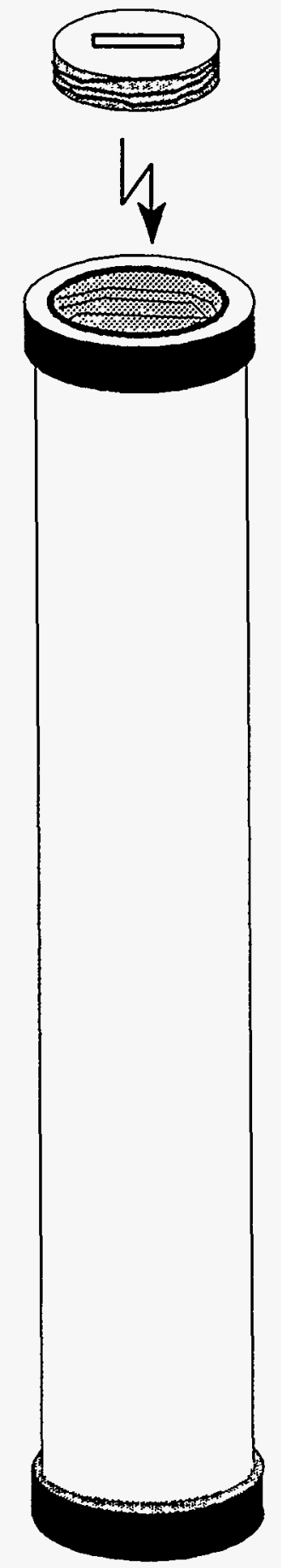

\section{Detail PVC Source Tube}

NOTE: Like sources inserted in tube and logged.

Metal canister may be of similar design

- Normal form source 

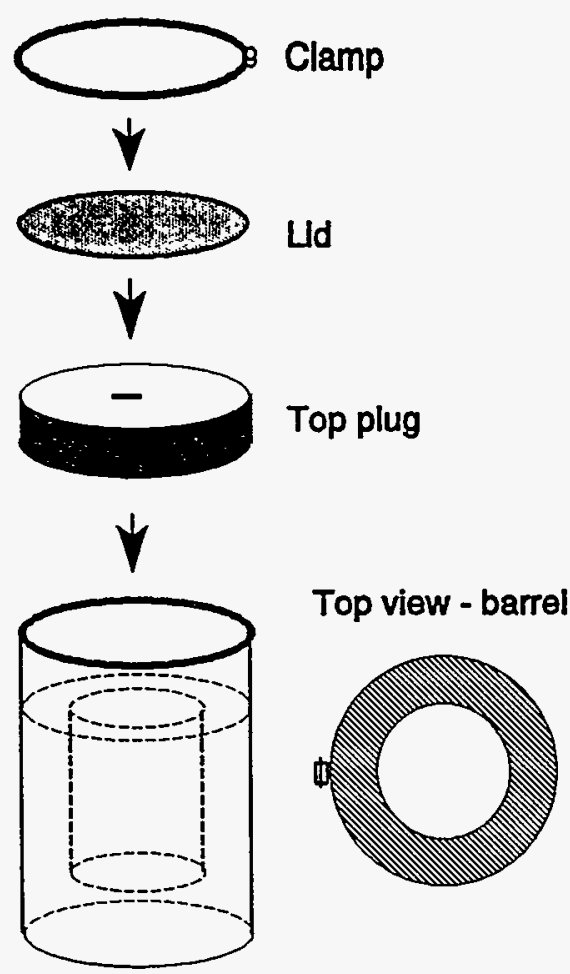

DOT Type A

Spoc. 7A

55-gal. drum

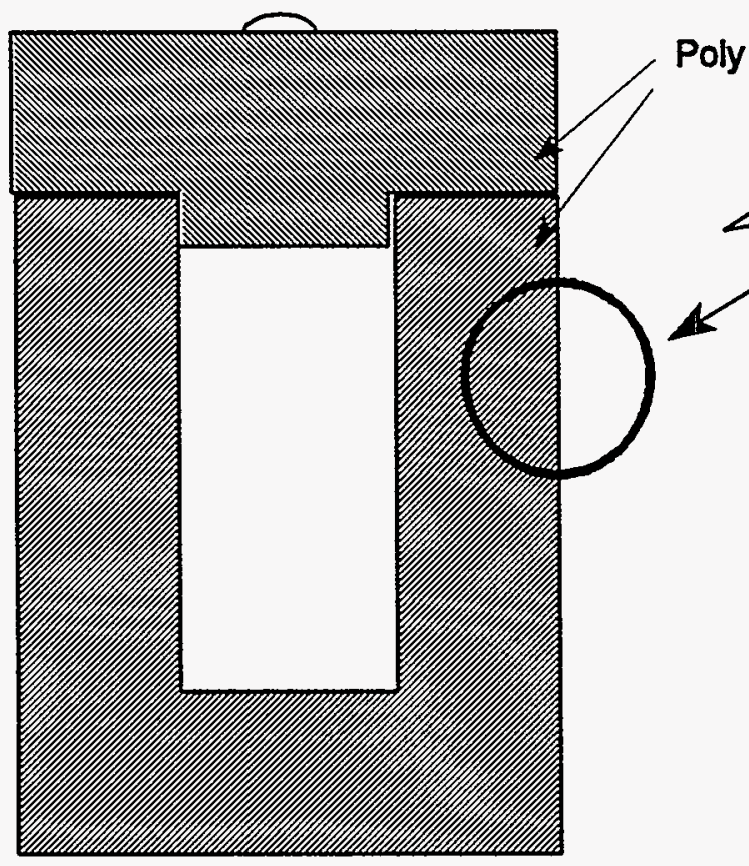




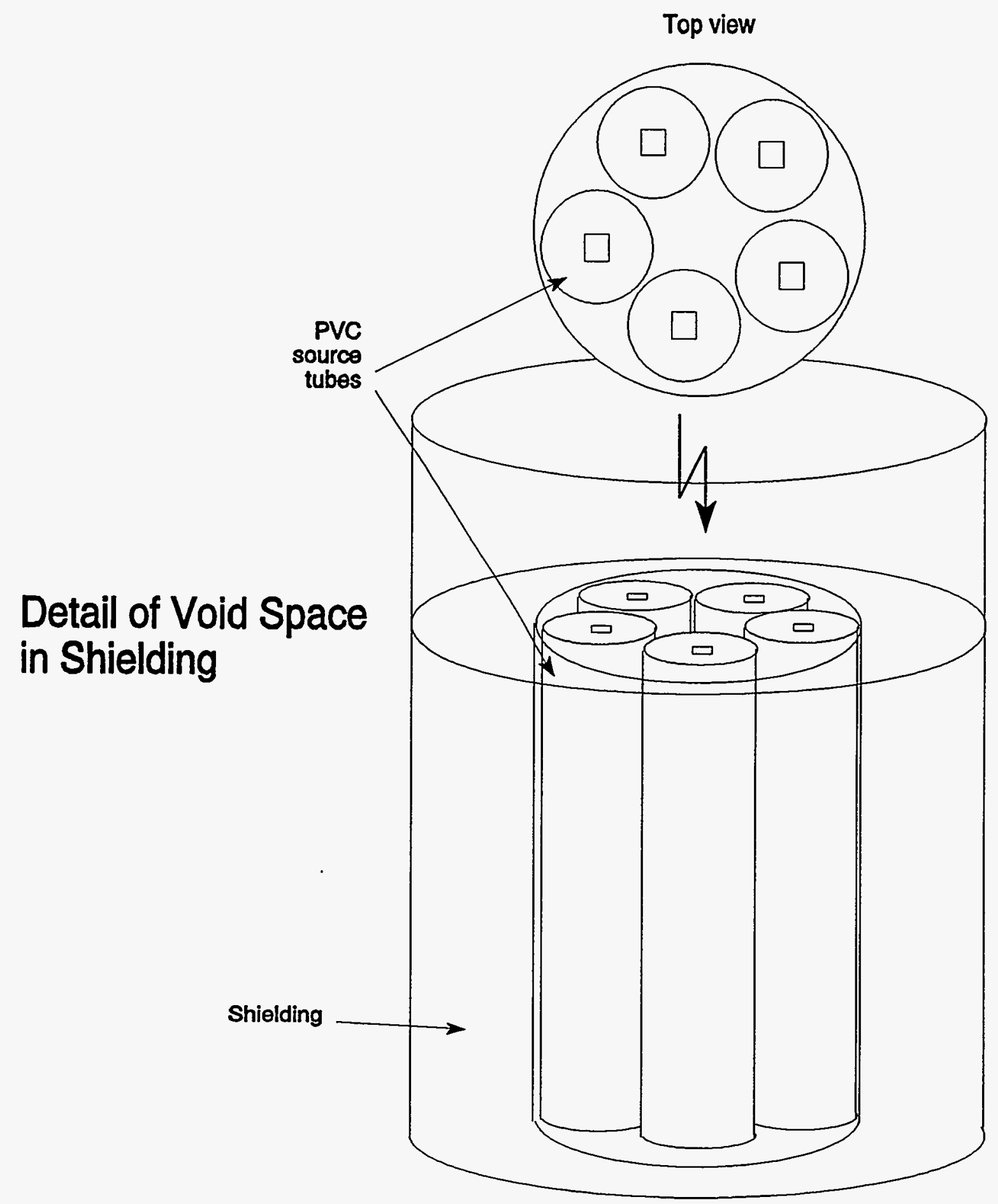

D940056I 